\title{
Water scarcity and fish imperilment driven by beef production
}

\author{
Brian D. Richter ${ }^{1,2 \bowtie}$, Dominique Bartak ${ }^{3}$, Peter Caldwell ${ }^{4}$, Kyle Frankel Davis ${ }^{5,6,7}$, \\ Peter Debaere ${ }^{8}$, Arjen Y. Hoekstra ${ }^{9}$ 9,10, Tianshu Li ${ }^{11}$, Landon Marston ${ }^{12}$, Ryan McManamay ${ }^{13}$, \\ Mesfin M. Mekonnen ${ }^{14}{ }^{14}$, Benjamin L. RuddelI ${ }^{15}$, Richard R. Rushforth ${ }^{15}$ and Tara J. Troy $\circledast^{16,17}$
}

\begin{abstract}
Human consumption of freshwater is now approaching or surpassing the rate at which water sources are being naturally replenished in many regions, creating water shortage risks for people and ecosystems. Here we assess the impact of human water uses and their connection to water scarcity and ecological damage across the United States, identify primary causes of river dewatering and explore ways to ameliorate them. We find irrigation of cattle-feed crops to be the greatest consumer of river water in the western United States, implicating beef and dairy consumption as the leading driver of water shortages and fish imperilment in the region. We assess opportunities for alleviating water scarcity by reducing cattle-feed production, finding that temporary, rotational fallowing of irrigated feed crops can markedly reduce water shortage risks and improve ecological sustainability. Long-term water security and river ecosystem health will ultimately require Americans to consume less beef that depends on irrigated feed crops.
\end{abstract}

W ater shortages have afflicted human societies for thousands of years ${ }^{1}$. As population centres grow and farmlands expand, freshwater consumption typically increases until renewable water supplies are fully utilized (for example, in Fig. 1); at this point, water users and freshwater ecosystems become highly vulnerable to water shortages during drier periods ${ }^{2}$. Historically, water shortages had local causes and consequences, involving only the communities that were directly dependent on an overused river or aquifer. Today, however, with trade networks encircling the globe, demand for asparagus in the United Kingdom can contribute to the depletion of an aquifer in the Peruvian desert ${ }^{3,4}$ and water shortages in the Central Valley of California can affect the availability and price of almonds and pistachios imported into the European Union ${ }^{5}$.

Climate change exacerbates water shortages by affecting both water supplies and water demands. Higher temperatures increase evapotranspiration, reducing aquifer recharge and watershed runoff $^{6}$. For example, Udall and Overpeck attributed one-third of recent declines in Colorado River flows (19\% below average during 20002014) to temperature increases ${ }^{7}$. The Intergovernmental Panel on Climate Change expressed high confidence that irrigation-the largest water-using sector globally-will increase in coming decades due to increased evapotranspiration ${ }^{6}$.

Human-induced depletion of river flows has deleteriously affected freshwater species and ecosystems across the globe ${ }^{8,9}$ and is a leading cause of fish imperilment in the US ${ }^{10-12}$. Richter et al. ${ }^{12}$ documented that $62 \%$ of sub-watersheds in the western US contain at least one species endangered by flow depletion, with a total of 367 plant and animal species affected, including two-thirds of all native fish species in the Colorado River basin. To protect species listed under the US Endangered Species Act, water regulators have been forced to curtail water use for irrigation in some watersheds, leading to severe political controversy and economic hardship ${ }^{13,14}$. The annual cost of recovering Endangered Species Act-listed fish species (more than US\$800 million per year) now exceeds expenditures for all other animal and plant groups combined ${ }^{15}$.

Water shortages have increased in both frequency and geographic extent in the US and globally ${ }^{16,17}$. However, some recent water shortages have begun to stimulate policy responses. A severe drought in California during 2012-2016 led to record levels of river and aquifer depletion across the state and US $\$ 2.7$ billion in agricultural losses in 2015 alone, provoking mandatory state-wide water use reductions and legislation requiring preparation of sustainable groundwatermanagement plans ${ }^{18,19}$. In recent decades, water extractions from the Colorado River have exceeded total river flow, causing rapid depletion of water-storage reservoirs (Fig. 1). In response, state and federal water agencies are preparing demand-management plans to stabilize reservoir levels and avoid mandatory reductions in water deliveries to states sharing the basin's water ${ }^{20-22}$.

For water-management plans and policies to succeed, they need sufficiently detailed and accurate information that can enrich understanding of the causes of water shortages and help guide decision making around potential solutions. Here we assess river flow depletion across the US, identify direct and indirect drivers of this depletion, and assess options to reduce vulnerability to water shortages.

Our findings led to closer examination of the water use and ecological impacts associated with irrigation of cattle-feed crops. We

'Sustainable Waters, Crozet, VA, USA. ${ }^{2}$ University of Virginia, Charlottesville, VA, USA. ${ }^{3}$ Water Asset Management, San Francisco, CA, USA. ${ }^{4}$ USDA Forest Service, Southern Research Station, Otto, NC, USA. ${ }^{5}$ Department of Geography and Spatial Sciences, University of Delaware, Newark, DE, USA. ${ }^{6}$ Department of Plant and Soil Sciences, University of Delaware, Newark, DE, USA. ${ }^{7}$ Data Science Institute, Columbia University, New York, NY, USA. ${ }^{8}$ Darden School of Business, University of Virginia, Charlottesville, VA, USA. ${ }^{9}$ Twente Water Center, University of Twente, Enschede, The Netherlands. ${ }^{10}$ Institute of Water Policy, Lee Kuan Yew School of Public Policy, National University of Singapore, Singapore, Singapore. "Institute of Urban Development, Nanjing Audit University, Nanjing, Jiangsu, China. ${ }^{12}$ Civil Engineering Department, Kansas State University, Manhattan, KS, USA. ${ }^{13}$ Department of Environmental Science, Baylor University, Waco, TX, USA. ${ }^{14}$ Robert B. Daugherty Water for Food Global Institute, University of Nebraska, Lincoln, NE, USA. ${ }^{15}$ Northern Arizona University, Flagstaff, AZ, USA. ${ }^{16}$ Lehigh University, Bethlehem, PA, USA. ${ }^{77}$ University of Victoria, Victoria, British Columbia, Canada.

凶e-mail: brian@sustainablewaters.org 


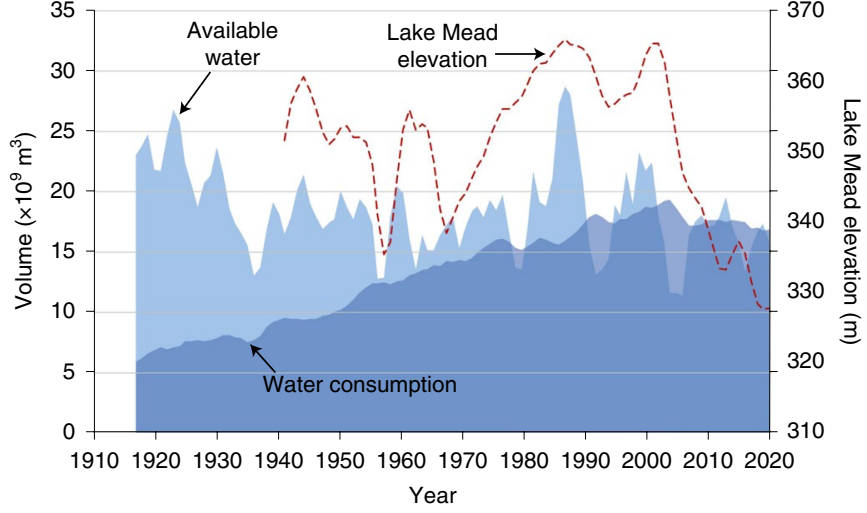

Fig. 1 | Water availability and use in the Colorado River basin. Over the past century, consumptive water uses in the basin increased steadily, to the point that annual consumption exceeded total river flows in $75 \%$ of years from 2000-2015. This over consumption has dried the river at its delta in Mexico and progressively depleted major storage reservoirs in the basin, including Lake Mead, posing severe risk of water shortage. All variables are portrayed as three-year running averages. Data source: US Bureau of Reclamation.

pinpointed locations where these crops were being grown and modelled their associated depletion of river flow in local sub-watersheds. We then conducted an international supply-chain analysis to identify the locations where cattle-feed crops are transported and where the resulting beef products are consumed, thereby linking end consumers of beef to effects on rivers. We subsequently explored the benefits and consequences of reduced feed-crop production and beef consumption through the lenses of water security, river ecosystem health, food security and agricultural economies.

\section{Key drivers of water shortages}

Following Brauman et al. ${ }^{17}$, we use a simple water depletion index (consumptive use/total renewable water) for assessing both vulnerability to water shortages and the likelihood of impacts on freshwater species due to reduced river flow. This depletion index reveals the proportion of annual renewable water supplies that are consumptively used within a given area and time period. Due to limitations of their hydrologic model (WaterGAP3), the Brauman study was able to calculate only a lumped depletion index for each watershed that combined surface and groundwater consumption. Given our interest in depletion of river flow and impacts to riverine species, we selected the water supply stress index (WaSSI) ecosystem services model, which can simulate the hydrologic impact of extractions from surface water and groundwater sources separately as well as hydrologic interactions between river flow and groundwater ${ }^{23,24}$. WaSSI operates on a monthly time step at the eight-digit hydrologic unit code (HUC8) sub-watershed scale. There are 2,099 HUC8 sub-watersheds in the conterminous US, with a mean area of $3,750 \mathrm{~km}^{2}$ (ref. ${ }^{25}$ ).

Our WaSSI modelling enabled us to connect water use to river flow depletion, and to link that depletion to specific sectors of water use and ecological impacts. We find summer depletion levels to be much greater than annual averages, more severe for 2001-2015 than for 1961-2015, and most severe during the driest $10 \%$ of years (Supplementary Fig. 1). Consistent with recent analysis ${ }^{26}$, we also find river flows to be much more depleted in the western half of the conterminous US, that is, in the 17 states lying on or west of the 100th meridian (Fig. 2). While these results are unsurprising, given the strong latitudinal gradients in precipitation and use of irrigation across the country (Table 1), this represents a first attempt, to our knowledge, to comprehensively quantify and separate flow depletion at the scale of HUC8 sub-watersheds and then attribute that depletion to specific water uses and ecological impacts.

Irrigated agriculture clearly has a dominant influence on river flow depletion across the western US (Table 1). More specifically, irrigation of cattle-feed crops (including alfalfa and grass hay and haylage, corn silage and sorghum silage) is the single largest consumptive user at both regional and national scales, accounting for $23 \%$ of all water consumption nationally, $32 \%$ in the western US and $55 \%$ in the Colorado River basin. Correspondingly, our hydrologic modelling reveals that cattle-feed irrigation is the leading driver of flow depletion in one-third of all western US sub-watersheds; cattlefeed irrigation accounts for an average of $75 \%$ of all consumptive use in these 369 sub-watersheds. During drought years (that is, the driest $10 \%$ of years), more than one-quarter of all rivers in the western US are depleted by more than $75 \%$ during summer months (Fig. 2 and Supplementary Fig. 2) and cattle-feed irrigation is the largest water use in more than half of these heavily depleted rivers.

An important caveat to these results is that inter-basin transfers of water (IBTs) were not included in our nationwide analysis due to a lack of contemporary data describing IBTs at the national scale ${ }^{27}$. This shortcoming does not affect our findings with respect to the consumption of water by various sectors, but it can lead to misleading conclusions about river flow depletion in some sub-watersheds because their water availability can be altered by imports or exports of water. As discussed later, we evaluate the influence of IBTs in the context of the Colorado River basin.

\section{Ecological consequences of flow depletion}

River flow depletion is a leading cause of aquatic species imperilment in the US, particularly for fish ${ }^{10,11}$. In addition to direct depletions of river flow by water diversions, pumping of shallow groundwater near rivers can reduce baseflow discharge to rivers.

We adopted an approach analogous to species-area modelling to evaluate one important aspect of ecological degradation: we estimated fish species losses to flow depletion at the sub-watershed (HUC8) scale ${ }^{28,29}$. While this approach does not consider other human disturbances (for example, water quality and habitat fragmentation), or invasive species effects, native fish richness shows consistent and predictable declines with losses in average flow magnitudes ${ }^{30,31}$. Using a regionally explicit predictive model relating natural summer flow magnitude with fish species richness $\left(r^{2}=0.80\right)$, we estimate the implications of summer flow depletion on the percentage of fish species potentially lost from each watershed (Fig. 3). As expected, patterns of impacts to fish richness closely mirror the summer flow depletion maps in Fig. 2.

We estimate that summer flow depletion (from all sources) is partially responsible for nearly 1,000 instances of increased risk of local extinction of fish species from watersheds in the western US (Supplementary Fig. 3). Of these, 690 (70\%) are estimated to have occurred primarily due to irrigation of cattle-feed crops. On the basis of species conservation status and trait information, we further translate local extinction instances to global imperilment risk. We estimate that 60 fish species in the western US are at elevated risk of imperilment or extinction due to flow depletion, and that 53 (88\%) of these are primarily due to irrigation of cattle-feed crops (Supplementary Fig. 4). These estimates closely align with empirical evaluations of fish species imperilment in the western US from flow alterations ${ }^{15}$.

Adverse ecological impacts in river systems result from multiple anthropogenic stressors, often with synergistic effects. This is particularly the case for flow reductions and water-quality impacts; human-induced flow reductions can concentrate problematic nutrient and chemical conditions, leading to eutrophication or depleted oxygen levels that are hazardous to fish and other aquatic organisms. Flow alterations can also shift competitive advantages to nonnative, invasive species introduced into the aquatic system; this is widely recognized as a serious problem in western US rivers ${ }^{11,31}$. 


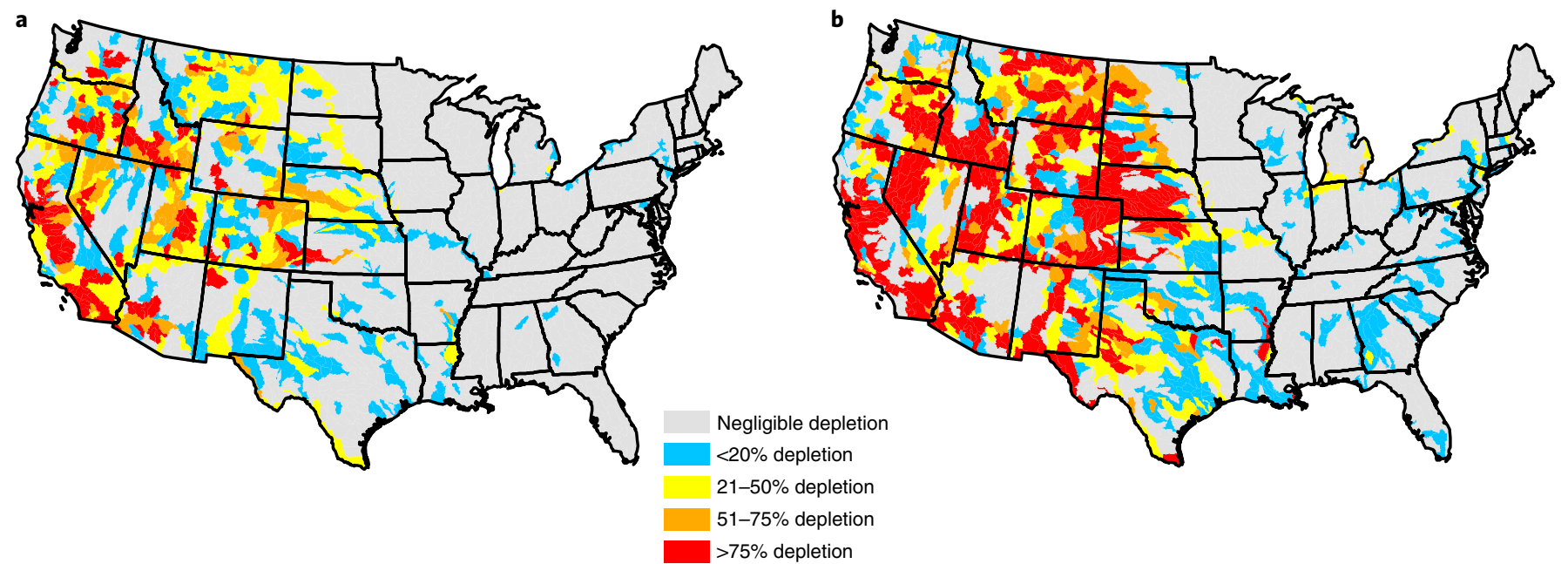

Fig. 2 | Depletion of river flow across the US during summer months. The 17 western states experience much higher levels of depletion during July to September than eastern states, owing to lesser precipitation and greater use of irrigation in the western states. a, Summer depletion during the $2001-2015$ model simulation. b, Summer depletion in the driest $10 \%$ of years during $1961-2015$.

\begin{tabular}{|c|c|c|c|c|c|c|}
\hline \multirow[t]{2}{*}{ Sector } & \multicolumn{2}{|c|}{ Conterminous United States } & \multicolumn{2}{|c|}{17 western states } & \multicolumn{2}{|c|}{ Colorado River basin ${ }^{a}$} \\
\hline & $\begin{array}{l}\text { Consumption } \\
\left(10^{6} \mathrm{~m}^{3} \mathrm{yr}^{-1}\right)\end{array}$ & $\begin{array}{l}\text { Percentage of } \\
\text { total consumption }\end{array}$ & $\begin{array}{l}\text { Consumption } \\
\left(10^{6} \mathrm{~m}^{3} \mathrm{yr}^{-1}\right)\end{array}$ & $\begin{array}{l}\text { Percentage of } \\
\text { total consumption }\end{array}$ & $\begin{array}{l}\text { Consumption } \\
\left(10^{6} \mathrm{~m}^{3} \mathrm{yr}^{-1}\right)\end{array}$ & $\begin{array}{l}\text { Percentage of } \\
\text { total consumption }\end{array}$ \\
\hline Domestic, self-supplied & 1,194 & 1 & 444 & 1 & 38 & 1 \\
\hline Domestic, public supply & 8,274 & 7 & 4,795 & 6 & 853 & 12 \\
\hline Commercial and industrial & 14,466 & 12 & 4,298 & 5 & 319 & 4 \\
\hline Thermoelectric power & 4,481 & 4 & 1,248 & 1 & 254 & 4 \\
\hline Crop irrigation ${ }^{\mathrm{b}}$ & 90,546 & 75 & 72,737 & 86 & 5,668 & 79 \\
\hline Alfalfa hay and haylage & 16,905 & 14 & 16,873 & 20 & 2,689 & 37 \\
\hline Other grass hay and haylage & 7,262 & 6 & 7,065 & 8 & 1,130 & 16 \\
\hline Corn silage & 3,406 & 3 & 3,328 & 4 & 154 & 2 \\
\hline Corn grain & 16,177 & 13 & 13,100 & 15 & 161 & 2 \\
\hline Wheat & 5,924 & 5 & 5,822 & 7 & 180 & 3 \\
\hline Cotton & 7,287 & 6 & 5,667 & 7 & 774 & 11 \\
\hline Soybeans & 9,079 & 7 & 3,368 & 4 & c & c \\
\hline Rice & 6,756 & 6 & 2,527 & 3 & c & c \\
\hline Almonds & 1,943 & 2 & 1,943 & 2 & c & c \\
\hline Potatoes & 1,555 & 1 & 1,465 & 2 & c & c \\
\hline Barley & 1,268 & 1 & 1,264 & 1 & 106 & 1 \\
\hline Other crops & 12,985 & 11 & 10,315 & 12 & 474 & 7 \\
\hline Livestock watering & 2,519 & 2 & 1,379 & 2 & 53 & 1 \\
\hline Mining & 50 & 0 & 21 & 0 & 2 & 0 \\
\hline Total & 121,530 & 100 & 84,922 & 100 & 7,187 & 100 \\
\hline
\end{tabular}

aEstimates for the Colorado River basin include only uses within the basin and do not include water exports from basin, reservoir evaporation or natural losses, which are included in Fig. 1. ${ }^{\mathrm{b}}$ Alfalfa hay and haylage, grass hay and haylage, and corn silage are cattle-feed crops; sorghum silage is a fourth cattle-feed crop assessed in this study, but its consumptive water use is negligible at these geographic scales. 'These crops are included as 'other crops' for the Colorado River basin because their percentages of total consumption were less than $1 \%$. In the 'Sector' column, bolded entries are major categories of water use and unbolded entries are sub-categories.

\section{Whose burgers are driving water scarcity?}

In order to gain a fuller understanding of the ultimate drivers of river depletion and ecological degradation, we traced the transport of irrigated feed crops and the beef produced from them, enabling us to identify whose burgers (and steaks) are causing river depletion in the western US. We assessed the geographic distribution of food production by using the Freight Analysis Framework (FAF) developed by Oak Ridge National Laboratory ${ }^{32}$ to map both the domestic and international transfers of virtual water associated with trade in irrigated cattle-feed crops as well virtual water consumed as beef (Fig. 4 and Supplementary Table 1). 


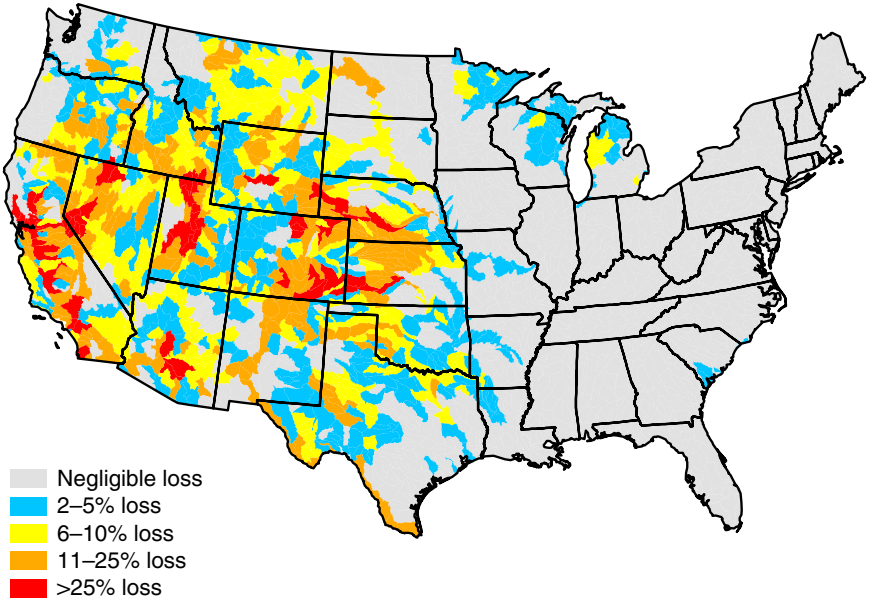

Fig. 3 | Estimated local eradication of fish species from sub-watersheds due to summer flow depletion in the US. This map shows the percentage of native fish species estimated to be eradicated from each sub-watershed according to our predictive model. Model predictions are based on depletions of summer flow during the 2001-2015 modelling period.

Nearly all US cattle-feed crops requiring irrigation are grown in the 17 western states. We estimate that two-thirds of the cattle feed being irrigated from western US rivers ends up as beef products, with the remainder going to dairy products. The areas of the western US most heavily dependent on rivers to irrigate cattle-feed crops are shown in Fig. 4a and Supplementary Fig. 2. The patterns in these figures mirror our depletion maps in Fig. 2 to some degree, because irrigation of cattle-feed crops is the dominant water consumer in the western US. Half of all irrigated cattle-feed crops are transported out of the county of origin; as of $2012,8 \%$ of these crops were being exported outside of the US for beef production in other countries (primarily to Canada, Japan, South Korea and Mexico). In recent years, exports to China have increased substantially, causing total cattle-feed exports to rise to $10-12 \%$ of total production (https://www.ers.usda.gov/webdocs/DataFiles/51875/MeatSDFull. $\mathrm{xlsx}$ ? $\mathrm{v}=5810.6$ )

The resultant virtual water consumption associated with beef consumption is shown in Fig. $4 \mathrm{~b}-\mathrm{d}$. More than $90 \%$ of all beef consumed in the US is produced internally; only about $10 \%$ of US beef production is exported internationally (Fig. 4b). In the US, consumption of beef grown on river-irrigated feed crops is highly concentrated in large urban metropolitan areas, as would be expected (Fig. 4c); the top five consumption centres include Los Angeles-Long Beach (CA); Portland-Salem (OR); Denver-Aurora (CO); San Francisco-Oakland-San Jose (CA); and Seattle-Tacoma (WA). On a per-capita basis, other consumption centres become important, with Laredo, Texas topping the list, followed by the Portland (OR) (Fig. 4d). We were also able to identify the largest consumers of beef produced from cattle feeds irrigated in specific river basins, enabling us to document, for example, that beef eaters in Los Angeles-Long Beach (CA), Denver-Aurora (CO) and San Francisco-Oakland-San Jose (CA) are most responsible for water scarcity related to cattle-feed production in the Colorado River basin (Supplementary Table 1).

\section{Seeking solutions to scarcity}

Successfully reducing the risks of water shortages and freshwater species imperilment in the US will require concerted effort by all water users to reduce their consumptive use. The US has made notable progress in reducing overall water withdrawals in recent decades, returning to pre-1970 levels despite an increasing population and economic growth ${ }^{33}$. Many cities such as Denver and Los Angeles-both of which draw much of their water supply from the Colorado River via IBTs-have been able to lower their total water use by more than $20 \%$ over recent decades even while their populations have increased ${ }^{34}$. Additionally, consumptive water use in irrigated agriculture has declined at the national level since $1995^{33}$. In the Supplementary Information, we discuss the success of two large irrigation districts in California that have lowered their annual consumptive use by one-third, on average. However, given that many water sources across the western US have been severely depleted for decades and remain so today (Figs. 1 and 2), much greater effort in reducing water consumption will be needed to improve water security and ecological health.

One strategy that is increasingly being applied in the western US for reducing water shortage risk is offering financial incentives for the voluntary, temporary, rotational fallowing of farmland as a means for reducing consumptive water use. We sought to better understand the water-saving potential and cost of these fallowing programmes, leading us to conduct an in-depth analysis of two of the largest ongoing fallowing programmes in the western US, which are taking place within the Palo Verde Irrigation District and the Imperial Irrigation District in southern California; our findings are summarized in our Supplementary Information. While many watersaving options are available to both cities and farms ${ }^{35}$, we focus on agricultural demand management because irrigated agriculture is by far the dominant water-consuming sector. And while there are many ways to reduce consumptive water use in irrigated agriculture, including improved irrigation equipment or scheduling, fallowing is quickly gaining popularity across the western US as a water-saving approach largely because: on a per-hectare basis it is at least twice as effective as other strategies for reducing water consumption ${ }^{35}$, meaning that it would require twice as much area for implementation of other strategies; farmer incomes can be enhanced when compensated with fallowing payments; it can be implemented intermittently and on a voluntary and rotational basis on a single farm or among farmers within an irrigation district; capital requirements are minimal; it maximizes water savings on farmland by eliminating irrigation; and resultant water savings are easier to calculate and monitor compared with other measures such as deficit irrigation or irrigation scheduling. Our focus on fallowing here should be taken not as a recommendation, but rather as an illustration of how water scarcity can be markedly alleviated.

\section{Colorado River basin case study}

The scope and location of fallowing programmes will need to be carefully targeted to avoid effects on food security while securing the volumes of water in the places where they are needed, including restoration of environmental flows for freshwater species. Here we illustrate how such targeting might be undertaken, using the Colorado River basin as an illustrative example. In this example, consistent with policy discussions currently underway, we assume that water saved through fallowing programmes in the basin will simply be allowed to remain within the river system, rather than be transported elsewhere for consumption. Instead, the saved water will flow into Lake Mead and Lake Powell, the main storage reservoirs in the river system, to reduce the likelihood of mandatory curtailments of Colorado River use.

We first assessed the influence of cattle-feed crop irrigation and IBTs on summer flow depletions in the Colorado River basin during the 2001-2015 simulation period (Supplementary Table 2). The river's natural summer flow is abruptly depleted in the headwater subwatersheds by large IBTs that divert nearly $20 \%$ of the natural flow through the Rocky Mountains (Fig. 5), delivering water to Denver and other 'front range' cities in Colorado. The impact of these headwater IBTs is attenuated in a downstream direction as tributary inflows enter the Colorado River mainstem, but their effects 


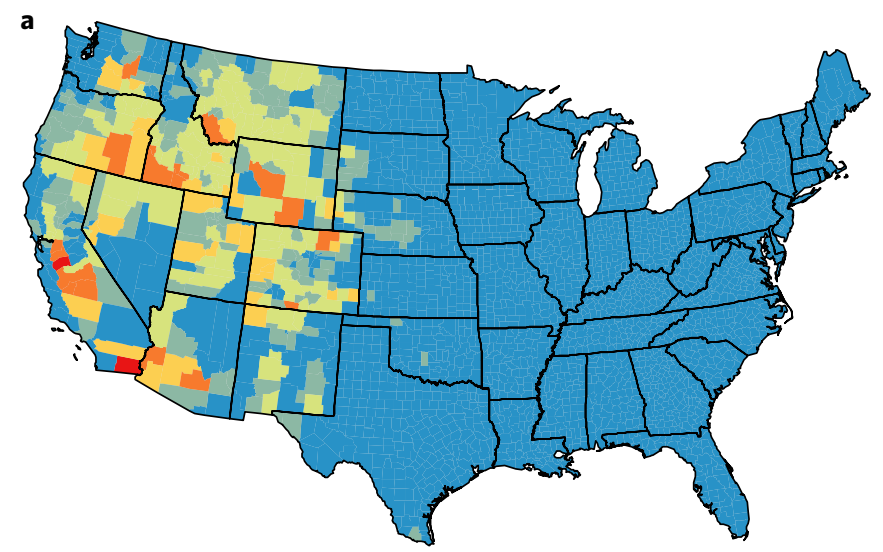

b

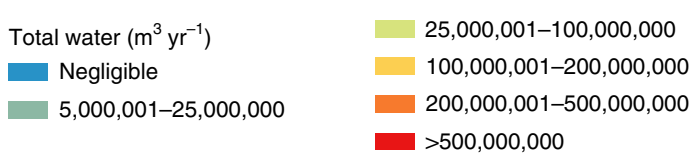

\begin{abstract}
25,000,001-100,000,000
$100,000,001-200,000,000$

200,000,001-500,000,000

$>500,000,000$
\end{abstract}

c

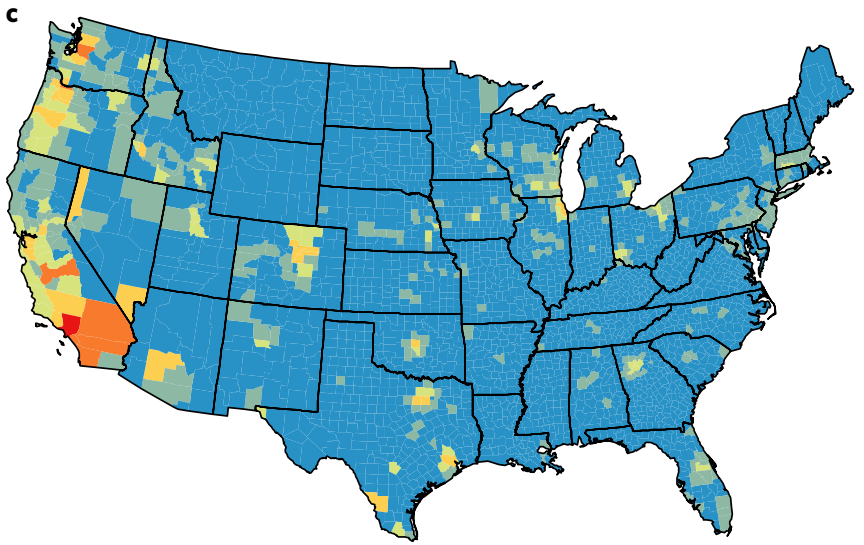

Total water $\left(\mathrm{m}^{3} \mathrm{yr}^{-1}\right)$

Negligible

1,000,001-5,000,000

$5,000,001-20,000,000$
Fig. 4 | Consumption of irrigation water sourced from western US rivers and used in producing cattle-feed crops and beef. a, Annual volume of irrigation water consumed in producing cattle-feed crops. b, Irrigation water virtually embedded in beef consumption globally. c, Irrigation water virtually embedded in beef consumption domestically. d, Irrigation water virtually embedded in per-capita domestic beef consumption. The western US accounts for $99 \%$ of irrigated cattle-feed crops in the country and more than $90 \%$ of beef consumed in the US is produced internally. persist far downstream. As mentioned previously, depletions due to IBTs are not yet accounted for in other river basins in our WaSSI hydrologic model; their eventual inclusion may change the depletion status of some watersheds that are either donors or recipients of these IBTs (see Supplementary Fig. 6 for the influence of IBTs in the Colorado River basin).

Adding to the depletion effects of IBTs, irrigation of cattle-feed crops depletes another $17-21 \%$ of the river's flow throughout the upper basin, increasing to $26 \%$ in the lower basin. Whereas IBTs are the primary cause of depletions in the topmost headwater areas, irrigation of cattle-feed crops (particularly alfalfa and other hay and haylage) quickly becomes the biggest driver of flow depletion for most of the river's length, continuing all the way downstream to the US-Mexico border.

The seven states sharing the river's water are now discussing demand-management goals to reduce consumptive water use and stabilize reservoir levels that have been declining for decades (Fig. 1).
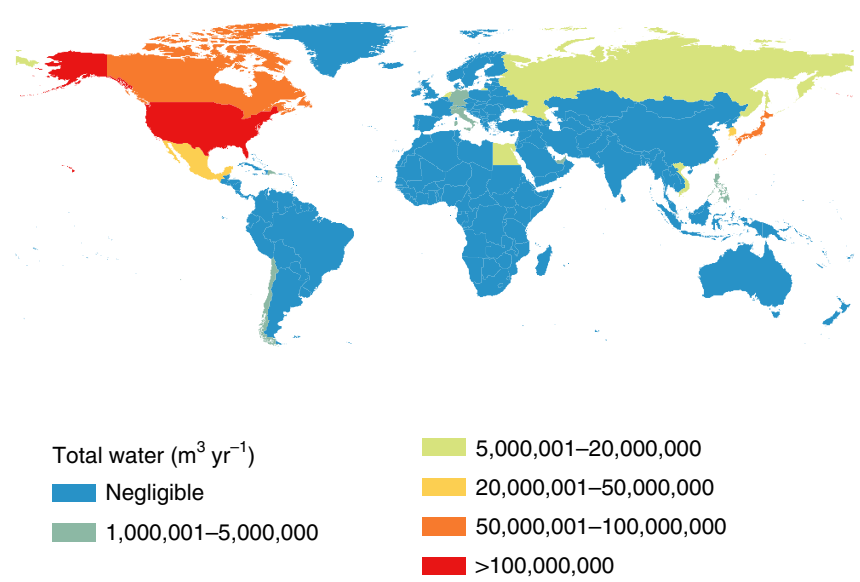

d

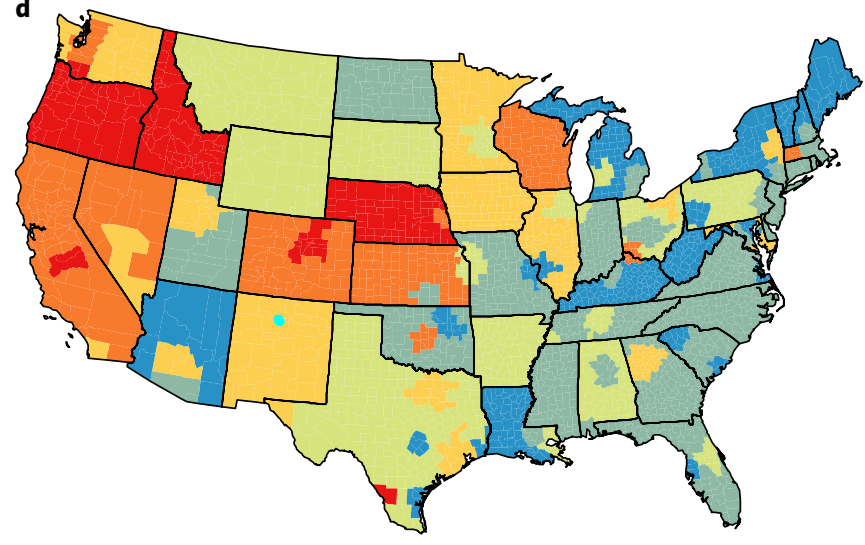

Per capita water $\left(\mathrm{m}^{3} \mathrm{yr}^{-1}\right)$

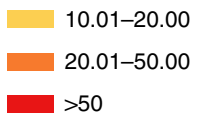

Negligible

$1.01-5.00$

$>50$

$5.01-10.00$
We explored a range of fallowing scenarios in which we temporarily take varying proportions of the cattle-feed crops in the Colorado River basin out of production to evaluate potential increases in summer river flow and reductions in our depletion index. We assessed how much rotational fallowing would be required to meet demand-management goals currently being discussed among both the upper and lower basin states $^{20-22}$ as well as to provide a 'moderate' level of ecological protection (that is, less than $20 \%$ depletion) as suggested by Richter et al. ${ }^{36}$. Our findings are summarized in Supplementary Table 3.

Meeting the demand-management goal $\left(123 \times 10^{6} \mathrm{~m}^{3} \mathrm{yr}^{-1}\right)$ designed to avoid water shortages in the upper Colorado River basin can be achieved with temporary, rotational fallowing of $20 \%$ of cattle-feed crops. In the lower basin, meeting the low-end target for water savings $\left(420 \times 10^{6} \mathrm{~m}^{3} \mathrm{yr}^{-1}\right)$ can be achieved with fallowing of $44 \%$ of cattle-feed crops, but the high-end target $\left(1,480 \times 10^{6} \mathrm{~m}^{3} \mathrm{yr}^{-1}\right)$ cannot be met by fallowing alone; a combination of fallowing and reduction in IBTs will be required. 


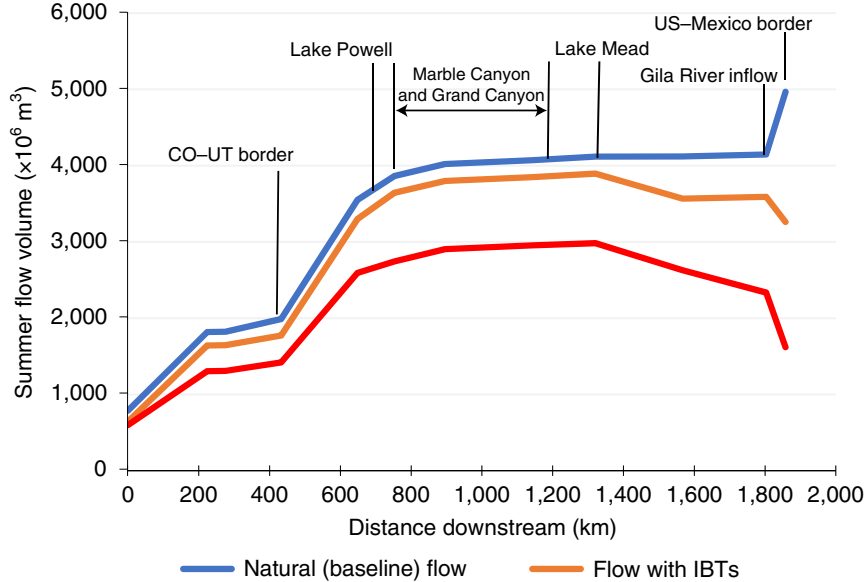

Flow with IBTs and all water uses

Fig. 5 | Depletion of the Colorado River along its length in summer.

Approximately one-fourth of the average summer flow is depleted throughout much of the river's length, increasing to two-thirds in its lowest reaches as it approaches the US-Mexico border. In the topmost headwater areas, IBTs of water to cities east of the Rocky Mountains are the primary cause of depletion, but irrigation of cattle-feed crops becomes the largest influence on the remainder of the river. Based on the model simulation for 2001-2015.

Importantly, our findings are based on fallowing only during July to September, which may create an opportunity to continue producing cattle-feed crops at other times, depending on location in the Colorado River basin. Given that the production of irrigated cattlefeed crops in the entire basin amounts to less than $5 \%$ of the total US production of these crops, only minimal effects on national or international food security would be expected.

Finally, using the average water prices for fallowing in the Imperial and Palo Verde irrigation districts (see analysis in Supplementary Information), we expect the cost of attaining the demand-management goals would be at least US $\$ 19$ million per year for the upper basin and between US\$63-222 million per year for the lower basin. Clearly, over-allocation of our water resources can be a very costly mistake, but it may also be an affordable one to correct if the costs to rectify such over-allocation are shared among the 40 million consumers of the Colorado River water or among 327 million Americans.

\section{Discussion}

In this study, we identify cattle-feed irrigation as the proximate driver, and beef consumption as the ultimate driver, of river depletion, water shortages and fish species imperilment in the western US. In the US overall, beef consumption contributes $22 \%$ to the total water footprint of American consumers ${ }^{37,38}$; beef consumption in the US $(36.2 \mathrm{~kg}$ per person per year) is 3.9 times the world average $(9.3 \mathrm{~kg}$ per person per year ${ }^{39}$. The US is also a major producer of beef, accounting for $18 \%$ of global beef production in $2017^{39}$. This supports the finding that beef production and consumption is a major factor in the pressure on freshwater resources in the US, but it is also important to note that US beef consumption is so large that the country must also import around $10 \%$ of its beef ${ }^{10}$, suggesting that the beef consumption may also have effects on water resources outside the US.

This study is the first, to our knowledge, to link beef consumption and its water footprint to depletion of specific river systems. We conclude that beef consumption is having a large impact on many western US rivers and their ecological health (Supplementary Fig. 2). Irrigation of cattle-feed crops is the leading use of water from half of the region's most depleted rivers. Beef consumers living in the Los Angeles, Portland, Denver and San Francisco metropolitan areas bear the greatest responsibility for these hydrological and ecological impacts.

Our economic evaluation of one increasingly popular solutionvoluntary, rotational fallowing of irrigated cattle-feed crops to reduce water consumption-suggests that this strategy can be applied at a scale that substantially reduces water shortage risks while benefitting farmers financially and minimizing food-security risks. Ultimately, water security and river health in the western US will depend on the willingness of urban and rural water users to collaborate in design of demand-management strategies, the ability of political leaders to secure funding to implement those strategies, and the willingness of beef and dairy consumers to reduce their consumption or select products that do not depend on irrigated cattle-feed crops.

Well-designed informational databases can be powerful tools for guiding natural resource policymaking. When addressing risks of water shortage, it is critically important to understand how water resources are being used consumptively, and the ecological and economic consequences of water use. It is also important to understand the specific end consumers or constituencies that may be affected by any proposed changes in water or land use. A key challenge of policy design is to impose sufficient change in resource use to substantially alleviate undesirable risks while avoiding unnecessary hardship to any parties.

\section{Methods}

The data sources and analytical approaches used in this study are summarized below.

National hydrology model. The WaSSI ecosystem services model was developed by the US Department of Agriculture Forest Service, and has been extensively tested using observed stream flow measurements ${ }^{41,42}$, with excellent predictive performance relative to other continental and basin scale models ${ }^{43}$. WaSSI computes the full water balance at monthly time intervals and accumulates water yield through the river network. Details on model computations can be found in refs. ${ }^{41,42}$. Modifications to WaSSI for this study are as follows.

The net stream flow $\left(Q_{\text {net } h}\right)$ at the outlet of each HUC8 $h$ after accounting for water use was calculated as:

$$
Q_{\text {net }}=\sum Q_{\text {ups }}+Q_{\text {gen }}-S W U_{\text {net }}-\mathrm{GWU}_{\text {net }}
$$

where $Q_{\text {ups }}$ is the sum of flows entering the HUC8 from upstream HUC8s, $Q_{\text {gen }}$ is the stream flow generated within the HUC8 calculated by local water balance, $\mathrm{SWU}_{\text {net }}$ is the effect of net surface water use in the HUC8 on stream flow, and $\mathrm{GWU}_{\text {net }}$ is the effect of net groundwater use in the HUC8 on stream flow. Shape files for HUC8 boundaries were obtained from the US Department of Agriculture ${ }^{44}$

The net surface water use $\left(\mathrm{SWU}_{\mathrm{net}}\right)$ for each HUC8 was calculated as:

$$
\mathrm{SWU}_{\text {net }}=\sum_{i=1}^{4} \mathrm{SWW}_{i}-\sum_{i=1}^{4} \mathrm{SWR}_{i}+\mathrm{SWC}_{\mathrm{LIV}}+\mathrm{SWC}_{\mathrm{MIN}}
$$

where $\mathrm{SWW}_{i}$ is the gross surface water withdrawal by sector $i$ (domestic, DOM; commercial and industrial, CII; thermoelectric, TRM; and irrigation, IRR sectors), and $\mathrm{SWC}_{\mathrm{LIV}}$ and $\mathrm{SWC}_{\mathrm{MIN}}$ are the surface water consumption for the livestock and mining sectors, respectively. $\mathrm{SWC}_{\mathrm{LIV}}$ and $\mathrm{SWC}_{\mathrm{MIN}}$ were used because gross water withdrawals were not available for these sectors. $\mathrm{SWR}_{i}$ is the surface water return flows to surface water from sector $i$, calculated as:

$$
\mathrm{SWR}_{i}=\left(\mathrm{SWW}_{i}-\mathrm{SWC}_{i}\right) \mathrm{RFF}_{-} \mathrm{SW}_{i}
$$

where $\mathrm{SWW}_{i}$ is gross surface water withdrawal, $\mathrm{SWC}_{i}$ is consumptive surface water

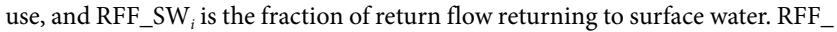
$\mathrm{SW}_{\mathrm{DOM}}, \mathrm{RFF}_{\mathrm{S}} \mathrm{SW}_{\mathrm{CII}}$, and RFF_SW $\mathrm{TRM}_{\mathrm{T}}$ were assumed to equal 1.0 (that is, all return flows for these sectors return to surface water). This assumption is reasonable because unconsumed water for these sectors are generally discharged directly to surface water bodies through water-management infrastructure (for example, water treatment plants).

Return flow for irrigation water applied to agricultural lands will partly run off to surface water directly and/or through shallow groundwater discharge to streams, or will recharge deeper groundwater aquifers. RFF_SW IRR $_{\text {will be greater in areas }}$ that are artificially drained, such as through ditches or subsurface drainage tiles. Following Döll et al. ${ }^{37}$, RFF_SW IRR $_{\text {was calculated as: }}$

$$
\text { RFF_SW } \text { IRR }=0.2+0.6 f_{\mathrm{d}-\mathrm{IRR}}
$$

where $f_{\text {d_IRR }}$ is the proportion of irrigated area that is artificially drained ${ }^{38}$. To our knowledge, there are no data describing the aquifer sources of groundwater 
withdrawals for each water use sector at the national scale. As a result, we could not quantify the extent to which groundwater pumping may deplete stream flow. We assumed that all groundwater withdrawals were supplied by an isolated aquifer disconnected from surface water. However, return flows from groundwater withdrawals were assumed to discharge to surface water except in areas where groundwater aquifers are over-exploited (that is, groundwater withdrawal exceeds the rate of recharge). We identified HUC8s where the ratio of groundwater extraction to recharge exceeded 1.0 (ref. ${ }^{39}$ ). In these areas, we assumed that RFF_SW was equal to 0 . The net groundwater use effect on surface water $\left(\mathrm{GWU}_{\text {net }}\right)$ was computed as:

$$
\mathrm{GWU}_{\text {net }}=-\sum_{i=1}^{4} \mathrm{RFF}_{\mathrm{SWW}}\left(\mathrm{GWW}_{i}-\mathrm{GWC}_{i}\right)
$$

where $\mathrm{GWW}_{i}$ is the gross groundwater withdrawal, and $\mathrm{GWC}_{i}$ is the consumptive groundwater use.

Water withdrawals and consumption. Crop-specific irrigated area. Crop-specific irrigated areas for the year 2012 were derived in two steps. We first resampled the datasets on irrigated extent (MIrAD-US ${ }^{40}$ ) and crop-specific land cover (US Department of Agriculture's cropland data layer ${ }^{45}$ ) into $1 \mathrm{~km} \times 1 \mathrm{~km}$ grid cells. We then estimated crop-specific irrigated extent using the MIrAD-US data on irrigated extent ${ }^{40}$ to mask the crop-specific cropland data layer data ${ }^{45}$

Monthly blue water footprint of crop production. Gridded ( 5 arcmin) monthly blue crop water use (CWU, expressed in $\mathrm{m}^{3} \mathrm{ha}^{-1}$ ) for 99 crops-averaged over the period 19962005-was taken from Mekonnen and Hoekstra ${ }^{46}$, who used a grid-based dynamic water balance model that calculate a daily root-zone soil water balance, crop water requirements, irrigation volumes in irrigated croplands and actual evapotranspiration, where blue CWU was calculated as the difference between total CWU under irrigated conditions and the green CWU under rainfed conditions. These crop-specific blue CWU data were then resampled to match the spatial resolution of the crop-specific irrigated area data. Finally, monthly blue water footprints (WF, expressed in $\mathrm{m}^{3}$ ) were estimated as the product of crop-specific monthly blue CWU and crop-specific irrigated area and then aggregated to HUC8 watershed level.

Crop water withdrawals. Crop-specific monthly HUC8-level consumptive blue water use values were disaggregated by source (surface or groundwater) and converted from consumptive use to withdrawals using 2010 county-level data from the US Geological Survey (USGS) ${ }^{47}$. Because water withdrawal data were not disaggregated by crop or by sector, we assumed that all crops within a county had the same ratio of surface:groundwater withdrawal and the same fractions of sprinkler-, micro- and surface (flood)-irrigated area. The HUC8-level irrigated areas $-m_{\mathrm{spr}, h}$ (sprinkler), $m_{\text {mic }, h}$ (micro) and $m_{\mathrm{flo}, h}$ (surface (flood))-for each irrigation method were calculated; for example:

$$
m_{\mathrm{spr}, h}=\sum_{c=1} \frac{a_{c, h} m_{\mathrm{spr}, c}}{a_{c}}
$$

where $a_{c, h}$ is the area of county $c$ contained within HUC8 $h, m_{\mathrm{spr}, c}$ is the area under sprinkler irrigation in county $c$, and $a_{c}$ is the county area. This calculation was repeated for $m_{\text {mic } h}$ and $m_{\mathrm{flo}, h}$. HUC8-level irrigation efficiency $\left(\eta_{h}\right.$; that is, the ratio of consumptive water use to withdrawal) was calculated as:

$$
\eta_{h}=\frac{0.8 m_{\mathrm{spr}, h}+0.9 m_{\mathrm{mic}, h}+0.7 m_{\mathrm{flo}, h}}{m_{\mathrm{spr}, h}+m_{\mathrm{mic}, h}+m_{\mathrm{flo}, h}}
$$

where the values of $0.8,0.9$ and 0.7 represent the average irrigation efficiencies for sprinkler, micro and surface (flood) irrigation, respectively ${ }^{48}$. As these efficiency estimates do not take into account efficiency (for example, non-productive losses of irrigation water in unlined canals), our estimates of freshwater withdrawals for crop irrigation are conservative.

HUC8-level blue surface $\left(w_{\mathrm{s}, h}\right)$ and groundwater withdrawals $\left(w_{\mathrm{g}, h}\right)$ were calculated using the same method as for calculating HUC8-level irrigated areas above. Monthly blue surface water withdrawal for crop $i$ in HUC8 $h$ during month $t\left(w_{\mathrm{s}, i h, t}\right)$ was calculated as:

$$
w_{\mathrm{s}, i, h, t}=\frac{w_{\mathrm{s}, h} b_{i, h, t}}{\left(w_{\mathrm{s}, h}+w_{\mathrm{g}, h}\right) \eta_{h}}
$$

where $b_{i, h, t}$ is the blue water consumption of crop $i$ in HUC8 $h$ during month $t$. Blue surface water consumption was calculated using the above equation omitting the $\eta_{h}$ term. These calculations were repeated to estimate the monthly blue groundwater withdrawal for the production of crop $i\left(w_{\mathrm{g}, i, h, t}\right)$ and the monthly blue groundwater consumption for the production of crop $i$, with $w_{\mathrm{g}, h}$ replacing $w_{\mathrm{s}, h}$ in the numerator.

Livestock watering. Livestock-specific, county-level annual groundwater and surface water withdrawals for livestock production were obtained from ref. ${ }^{49}$. HUC8-level blue surface water consumption was calculated as:

$$
b_{\mathrm{s}, h}=\sum_{c=1} \frac{a_{c, h} b_{\mathrm{s}, c}}{a_{c}}
$$

where $a_{c, h}$ is the area of county $c$ contained within HUC $h, b_{\mathrm{s}, c}$ is the blue surface water consumption of livestock in county $c$, and $a_{c}$ is the area of county c. This calculation was repeated to estimate the blue groundwater consumption of livestock $\left(b_{\mathrm{g}, h}\right)$. We assumed no return flows for livestock water use.

Public (domestic) water supply. Annual county-level domestic water withdrawals $\left(w_{\mathrm{d}, c}\right)$ for the year 2010 were taken from USGS ${ }^{47}$. Domestic water users receive their water either from a water utility (that is, domestic deliveries from public supply; $87 \%$ of total) or supply their own water from a private source (for example, a well or cistern; $13 \%$ ).

Public supply system delivered for domestic use. County-level domestic surface water consumption from public suppliers was calculated as:

$$
v_{\mathrm{d}, \mathrm{s}, c}=\alpha_{c} \beta_{c} w_{\mathrm{d}, c}
$$

where $\alpha_{c}$ is the fraction of public supply from surface water in county $c$ (ref. ${ }^{47}$ ) and $\beta_{c}$ is the ratio of domestic consumptive volume to delivery volume for county $c$ for the year 1995 (the most recent year for which this information was provided ${ }^{50}$. State-level estimates of $\beta_{c}$ were used if county-level values were not available. Return flows were the difference between delivery and consumptive volumes.

The annual withdrawal, consumption and return-flow values were temporally disaggregated using monthly water use distribution curves based on monthly water use data from ref. ${ }^{51}$ for 89 US cities during our study period. County-level domestic water use was proportionally assigned to $30 \operatorname{arcsec}\left(\sim 1 \mathrm{~km}^{2}\right)$-grid cells within the county on the basis of the relative (year 2010) population of each cell ${ }^{52}$ and then aggregated to the HUC8 scale.

Self-supplied water for domestic use. Annual county-level estimates of self-supplied domestic water withdrawals were again temporally disaggregated as above $\mathrm{e}^{51}$, with water consumption calculated using the same county-specific $\beta_{c}$ values. Selfsupplied county values were again transformed to the HUC8 scale as above, but only considering those population grid cells with less than 25 people, as the USGS defines self-supplied domestic water use as water delivered by a distribution system providing water to less than 25 people.

Commercial and industrial operations. County-level industrial withdrawals, consumption and return-flow data were derived from ref. ${ }^{49}$. These estimates were made following the same annual-to-monthly temporal disaggregation and county-to-HUC8 spatial redistribution as employed in calculating public supplied domestic water use.

Mining. County-level water consumption data for the mining sector were obtained from Marston et al. ${ }^{49}$. We employed a two-step method to convert county-level water use data to HUC8 watersheds. First, USGS data on active mines and mineral processing plant $\mathrm{s}^{53}$ were used to apportion mining activity between HUC8 watersheds within a county, assuming that each facility used water uniformly within a county. This assumption was necessary as facility-level water use data were not available. HUC8 Blue surface water consumption for mining in HUC8 $h\left(w_{\mathrm{s}, h}\right)$ was calculated as:

$$
w_{\mathrm{s}, h}=\sum_{c=1}\left(\frac{n_{c, h} w_{\mathrm{s}, c}}{n_{c}}\right)
$$

where $n_{c h}$ is the number of mining facilities in county $c$ contained within HUC8 $h, b_{\mathrm{s}, c}$ is the blue surface water consumption of mining in county $c$ and $n_{c}$ is the number of mining facilities in county $c$. This calculation was repeated to estimate the blue groundwater consumption of mining in HUC8 $h\left(b_{\mathrm{g}, h}\right)$.

This first-order disaggregation process is valid for counties that are responsible for $90 \%$ of mining water use in the U.S. For the remainder of the counties that do not have reported mines and mineral processing plants but do report mining water use, water use was disaggregated to the HUC8 level using the same method used for the livestock sector.

Thermoelectric power. Annual estimates of water withdrawals and consumptive use for 1,290 thermoelectric plants were taken from the USGS ${ }^{54}$; plants using saline or brackish water were omitted. Many plants did not report whether withdrawals were sourced from groundwater or surface water; if the water source was stated as 'wells' we assumed groundwater sourcing. All others were assumed to be sourced from surface water. The 1,290 plants included in the USGS dataset were supplemented by 818 additional thermoelectric plants from the US Energy Information Administration (EIA) form EIA $860^{55}$. For these additional plants, if water use data was available from ref. ${ }^{56}$, that data was used. Otherwise the methods used in ref. ${ }^{57}$ were used to estimate the cooling type with each primary mover; water use per MWh generation for different fuel-primary mover-cooling technologies is from ref. ${ }^{58}$.

To convert the annual water use to monthly estimates, monthly electricity generation values were taken from the EIA ${ }^{59}$. For those plants that were in both the annual water use database and the EIA electricity generation database, a ratio of the monthly generation to the total annual generation was used to downscale to 
monthly water withdrawals and consumption. For plants not in the EIA database, the nearest plant geographically that had both the same water use technology (for example, recirculating versus once-through) and water source was selected. This assumes that plants in the same geographical region are responding to the same seasonality in electricity demand for heating or cooling.

Using the provided geographic coordinates in each database, each plant was matched to a HUC8. Multiple plants using the same water source in a HUC were added together. Plants for which geographic coordinates were not available were excluded from the analysis.

Impacts of flow depletion on fish richness. We used a generalized linear mixed model to predict native fish richness (via Poisson distribution) for all HUC8 watersheds in the US based on average natural summer flows stratified by 29 ecohydrologic regions, representing unique spatial combinations of freshwater ecoregions and HUC-2 river basins. Native fish distributions per watershed were obtained from Nature Serve ${ }^{60}$. Generalized linear mixed models were developed using the lme4 package ${ }^{61}$ in the R programming environment. Average JulySeptember flows simulated by WASSI with no flow depletion (that is, natural flow) for the entire period (1961-2015) were modelled as random slopes for each ecohydrologic region (random intercepts). The model explained $80 \%$ of variation in observed fish richness and was used to predict fish richness for flow depletion scenarios for the 2001-2015 period. The total number of species lost per HUC8 watershed represented the total count of local extinctions; however, local extinction of species may not necessarily insinuate risk of global extinction for a species.

To estimate the risk of species to global extinction arising from water use scenarios, we first developed a ranking of all US fish species most vulnerable to extinction with respect to traits and limited geographical ranges predisposing them to negative effects of stream flow reduction. Rankings included consideration of Nature Serve global conservation status ${ }^{62}$ and a combination of habitat preferences, life histories, spawning flexibility or range restrictions that predispose species to being vulnerable to losses in stream flow. Species characteristics were obtained and modified from the FishTraits database ${ }^{63}$ and McManamay and Frimpong ${ }^{56}$. Species with Nature Serve conservation rankings of G1-G2 were scored as '2', G3-G4 as ' 1 ' and $\mathrm{G} 5$ as ' 0 '. Benthic affiliated species with preference for lotic habitats were scored as ' 1 ' and others were scored as ' 0 '. Species with high seasonal spawning fidelity were identified as species falling in the lowest 25 th percentile of spawning duration (months) among all species and scored as ' 1 '. Species with geographically restricted ranges were scored as ' 1 ' and identified as species falling in the lowest 25 th percentile of geographical ranges among all species. Equilibrium species tend to consistently respond negatively to losses in flow compared with opportunistic and periodic species ${ }^{56,64}$; however, given uncertainty in life history responses to flow reductions, these species were scored as ' 0.5 ' and others were scored as ' 0 '. Species vulnerability rankings represented a sum of all scores above with Nature Serve conservation scores weighted $2 \times$ other scores

Because species rankings are sensitive to approach and result in equal rankings among multiple species, we developed 50 scenarios of rankings using a randomization procedure to vary rankings by adding a variance component. Matrices representing species rankings, species distributions within HUC8 watersheds and estimated numbers of local extinctions per HUC8 were combined to estimate range reductions of most vulnerable species due to stream flow losses. Global vulnerability to extinction was based on the loss in each species' historical range, which was calculated as the sum of all areas of HUC8s associated with local extinctions for that species. Species with range reductions $\geq 30 \%$ or with resultant ranges $\leq 20,000 \mathrm{~km}^{2}$ were considered vulnerable to global extinction as a result of stream flow losses.

As a validation of our estimates of local extinctions and risk of global imperilment, we compared our findings with those of Richter et al. ${ }^{12}$, an empirical assessment of fish imperilment in the western US due to flow alteration. Richter et al. identified 669 total instances of fish imperilment in watersheds of the western US due to flow alteration, whereas our models estimated 721 instances of local extinction or imperilment. On an individual watershed-by-watershed basis, $60 \%$ of watersheds identified by Richter et al. as having imperilled fish from flow alteration were also identified as having at least 1 species at risk of local extinction from our estimates. Global risk of imperilment across 50 simulations resulted in an average probability of imperilment for a given fish species. We used area under-the-curve (AUC) analysis to determine the accuracy of our global imperilment probabilities relative to the findings of Richter et al. Global imperilment probabilities were compared to a binary indication of whether a given fish species was identified by Richter et al. as being imperilled or not due to flow alteration. For fish species of the western US, the AUC value was 0.70 .

Virtual water transport associated with cattle-feed crops and meat. Trade links beef consumers to water use for cattle and cattle feed. Because these are sometimes geographically distant connections, we quantified the fraction of stream flow depletion in the western US attributable to domestic and international exports of cattle feed and beef. To do this, we combined information on WFs for cattle feed with bilateral commodity flow data from two sources, the US Census Commodity Flow Survey (CFS) ${ }^{65}$ and FAF ${ }^{66}$. The CFS is a survey data product that contains selfreported commodity shipments by establishments located in the US. Trade data are reported for 132 domestic zones (corresponding to US metropolitan areas and rural portions of each state) and 8 world regions (Mexico, Canada, Europe, East Asia, Australia, Africa, southwest Asia and South America). For this analysis, we reduced the 132 domestic zones to 117 by combining cross-border metropolitan areas into single metropolitan areas (for example, St. Louis, MO and St. Louis, IL became St. Louis). Shape files for FAF zone and CFS metropolitan area boundaries came from the US Census ${ }^{67}$.

Commodity flow data are reported using Standard Classification of Transported Goods (SCTG) codes. Our assessment focused on SCTG 4 (animal feed, eggs, honey and other products of animal origin), SCTG 1 (live animals and fish) and SCTG 5 (meat, poultry, fish, seafood and their preparations). Commodity codes are bundles of related or similar products ${ }^{59}$. For example, SCTG 4 also includes non-meat animal by-products (for example, leather products), pet food, eggs and honey, in addition to animal feed ${ }^{68}$. The FAF dataset is built to include out-of-scope commodity flows into the CFS dataset. Importantly, these out-of-scope flows include agricultural products originating from the farm and comprehensive commodity export data ${ }^{69}$. However, the CFS dataset contains flows associated with a SCTG code and North American Industry Classification System code, whereas FAF does not. Conversely, the FAF contains farm-based flows, whereas the CFS does not. Therefore, the CFS dataset was used to remove unrelated commodity flows within a commodity code (for example, eggs) while retaining the farm-based commodity flows within each commodity code.

The SCTG 4 flows of non-related North American Industry Classification System codes in the CFS data were removed from FAF SCTG 4 data to produce an animal-feed flow (AFF) network from the place of feed production to the location of feed consumption by livestock. Using the AFF network and cattle population data $^{69}$, the feed demand associated with beef was estimated for each area producing beef. The total blue water footprint of beef cattle in each beef-producing area is the water they directly consume, as well as the blue water indirectly consumed through their diet (that is, water embedded within feed $)^{70}$. Beef cattle and their associated water footprint, are tracked as they move from their (1) rearing area to (2) finishing location to (3) slaughterhouse, and finally, (4) areas of beef consumption. This 'beef flow network' is derived from SCTG 1 (1-3) and SCTG 5 (4) commodity flow data using the same process to produce the AFF network. Areas of beef consumption were disaggregated to constituent counties (domestic consumption) and constituent countries (international consumption) using county-level population ${ }^{71}$ and country-level US beef export data ${ }^{72}$, respectively.

\section{Data availability}

All datasets used in this study are publicly available or available upon request from the authors.

\section{Code availability}

All computer code used in conducting the analyses summarized in this paper is available upon request from the authors.

Received: 21 February 2019; Accepted: 27 January 2020; Published online: 2 March 2020

\section{References}

1. Solomon, S. Water: The Epic Struggle for Wealth, Power, and Civilization (HarperCollins, 2011).

2. Richter, B. Chasing Water: A Guide for Moving from Scarcity to Sustainability (Island Press, 2014).

3. Hoekstra, A. Y. \& Mekonnen, M. M. The water footprint of humanity. Proc. Natl Acad. Sci. USA 109, 3232-3237 (2012).

4. Schwarz, E. \& Mathijs, E. Globalization and the sustainable exploitation of scarce groundwater in coastal Peru. J. Clean. Prod. 147, 231-241 (2017).

5. Ercin, A. E., Chico, D. \& Chapagain, A. K. Dependencies of Europe's Economy on Other Parts of the World in Terms of Water Resources (Water Footprint Network, 2016).

6. Jiménez Cisneros, B. E. et al. in Climate Change 2014: Impacts, Adaptation, and Vulnerability (eds Field, C. B. et al.) 229-269 (IPCC, Cambridge Univ. Press, 2014).

7. Udall, B. \& Overpeck, J. The twenty-first century Colorado River hot drought and implications for the future. Water Resour. Res. 53, 2404-2418 (2017).

8. Dudgeon, D. Prospects for sustaining freshwater biodiversity in the 21 st century: linking ecosystem structure and function. Curr. Opin. Environ. Sustain. 2, 422-430 (2010).

9. Horne, A. C. et al. (eds) Water for the Environment: From Policy and Science to Implementation and Management (Elsevier, 2017).

10. Reed, K. M. \& Czech, B. Causes of fish endangerment in the United States, or the structure of the American economy. Fisheries 30, 36-38 (2005).

11. Richter, B. D., Braun, D. P., Mendelson, M. A. \& Master, L. L. Threats to imperiled freshwater fauna. Conserv. Biol. 11, 1081-1093 (1997).

12. Richter, B. D., Powell, E. M., Lystash, T. \& Faggert, M. in Water Policy and Planning in a Variable and Changing Climate (eds Miller, K. A. et al.) Ch. 7 (CRC Press, 2016). 
13. AghaKouchak, A., Feldman, D., Hoerling, M., Huxman, T. \& Lund, J. Water and climate: recognize anthropogenic drought. Nature 524, 409-411 (2015).

14. Doremus, H. D. \& Tarlock, A. D. Water War in the Klamath Basin: Macho Law, Combat Biology, and Dirty Politics (Island Press, 2012).

15. Federal and State Endangered and Threatened Species Expenditures: Fiscal Year 2016 (US Fish and Wildlife Service, 2016).

16. Richter, B. D. et al. Tapped out: how can cities secure their water future? Water Policy 15, 335-363 (2013)

17. Brauman, K., Richter, B. D., Postel, S., Malsy, M. \& Flörke, M. Water depletion: an improved metric for incorporating seasonal and dry-year water scarcity into water risk assessments. Elementa 4, 000083 (2016).

18. Howitt, R., MacEwan, D., Medellín-Azuara, J., Lund, J. \& Sumner, D. Economic Analysis of the 2015 Drought for Agriculture (Univ. California, Davis, 2015).

19. Murray, K. D. \& Lohman, R. B. Short-lived pause in central California subsidence after heavy winter precipitation of 2017. Sci. Adv. 4, eaar8144 (2018)

20. Fialka, J. Lingering Colorado River drought could lead to water shortages. E\&E News (6 September 2018).

21. Romeo, J. Drought plan aims to curtail water loss at Lake Powell, Lake Mead. The Durango Herald (12 October 2018); https://durangoherald.com/ articles/245192

22. Agreement Concerning Colorado River Drought Contingency Management and Operations Exhibit 1 (US Bureau of Reclamation, 2019); https://go.nature. com/2OKDLhO

23. Sun, G. et al. Upscaling key ecosystem functions across the conterminous United States by a water-centric ecosystem model. J. Geophys. Res. 116, G00J05 (2011).

24. Caldwell, P. V., Sun, G., McNulty, S. G., Cohen, E. C. \& Moore Myers, J. A. Impacts of impervious cover, water withdrawals, and climate change on river flows in the conterminous US. Hydrol. Earth Syst. Sci. 16, 2839-2857 (2012).

25. Seaber, P. R., Kapinos, F. P. \& Knapp, G. L. Hydrologic Unit Maps WaterSupply Paper 2294 (U.S. Geological Survey, 1987).

26. Tidwell, V. C., Moreland, B. D., Shaneyfelt, C. R. \& Cobos, P. Mapping water availability, cost and projected consumptive use in the eastern United States with comparisons to the west. Environ. Res. Lett. 13, aa9907 (2018).

27. Emanuel, R. E., Buckley, J. J., Caldwell, P. V., McNulty, S. G. \& Sun, G. Influence of basin characteristics on the effectiveness and downstream reach of interbasin water transfers: displacing a problem. Environ. Res. Lett. 10, 124005 (2015)

28. Xenopoulos, M. A. et al. Scenarios of freshwater fish extinctions from climate change and water withdrawal. Glob. Change Biol. 11, 1557-1564 (2005)

29. Xenopoulos, M. A. \& Lodge, D. M. Going with the flow: using speciesdischarge relationships to forecast losses in fish biodiversity. Ecology 87, 1907-1914 (2006)

30. Freeman, M. C. \& Marcinek, P. A. Fish assemblage responses to water withdrawals and water supply reservoirs in Piedmont streams. Environ. Manag. 38, 435-450 (2006)

31. Poff, N. L. \& Zimmerman, J. K. Ecological responses to altered flow regimes: a literature review to inform the science and management of environmental flows. Freshw. Biol. 55, 194-205 (2010).

32. Hwang, H. et al. Building the FAF4 Regional Database: Data Sources and Estimation Methodologies (Oak Ridge National Laboratory, 2017).

33. Dieter, C. A. et al. Estimated use of water in the United States in 2015 Circular 1441 (US Geological Survey, 2018).

34. Dieter, C. A. et al. Estimated Use of Water in the United States County-Level Data for 2015 (USGS, 2018).

35. Richter, B. D. et al. Opportunities for saving and reallocating agricultural water to alleviate scarcity. Water Policy 19, 886-907 (2017).

36. Richter, B. D., Davis, M., Apse, C. \& Konrad, C. A presumptive standard for environmental flow protection. River Res. Appl. 28, 1312-1321 (2011).

37. Döll, P. et al. Impact of water withdrawals from groundwater and surface water on continental water storage variations. J. Geodynamics 59-60, 143-156 (2012).

38. Feick, S., Siebert, S., \& Döll, P. A Digital Global Map of Artificially Drained Agricultural Areas (Institute of Physical Geography, Univ. of Frankfurt, 2005); http://www.geo.unifrankfurt.de/ipg/ag/dl/publikationen/index.html

39. Reitz, M., Sanford, W. E., Senay, G. B. \& Cazenas, J. Annual estimates of recharge, quick-flow runoff, and evapotranspiration for the contiguous U.S. using empirical regression equations. J. Am. Water Resour. Assoc. 53, 961-983 (2017).

40. Moderate Resolution Imaging Spectroradiometer (MODIS) Irrigated Agriculture Dataset for the United States (MIrAD-US) (USGS, 2018)

41. Sun, S. et al. Drought impacts on ecosystem functions of the U.S. National Forests and Grasslands: part I evaluation of a water and carbon balance model. For. Ecol. Manag. 353, 260-268 (2015).
42. Caldwell, P., Sun, G., Tian, H. Q. \& Zeng, N. How well do terrestrial biosphere models simulate coarse-scale runoff in the contiguous United States? Ecol. Model. 303, 87-96 (2015).

43. Schwalm, C. R. et al. Upscaling key ecosystem functions across the conterminous United States by a water-centric ecosystem model. J. Geophys. Res. 116, G00J05 (2011).

44. Watershed Boundary Dataset (US Department of Agriculture, accessed July 2010); https://go.nature.com/2Hk9rpX

45. National Agricultural Statistics Service Cropland Data Layer, 2012 (US Department of Agriculture, 2017); https://nassgeodata.gmu.edu/CropScape/

46. Mekonnen, M. M. \& Hoekstra, A. Y. The green, blue and grey water footprint of crops and derived crop products. Hydrol. Earth Syst. Sci. 15, 1577-1600 (2011)

47. Maupin, M. A. et al. Estimated Use of Water in the United States in 2010 (USGS, 2014).

48. Dickens, J. M., Forbes, B. T., Cobean, D. S. \& Tadayon, S. Documentation of Methods and Inventory of Irrigation Data Collected for the 2000 and 2005 US Geological Survey Estimated Use of Water in the United States, Comparison of USGS-Compiled Irrigation Data to Other Sources, and Recommendations for Future Compilations (USGS, 2011).

49. Marston, L., Ao, Y., Konar, M., Mekonnen, M. M. \& Hoekstra, A. Y High-resolution water footprints of production of the United States. Water Resour. Res. 54, 2288-2316 (2018)

50. Solley, W. B., Pierce, R. R. \& Perlman, H. A. Estimated Use of Water in the United States in 1995 (USGS, 1998).

51. Chini, C. M. \& Stillwell, A. S. The state of U.S. urban water: data and the energy-water nexus. Water Resour. Res. 54, 1796-1811 (2018).

52. Center for International Earth Science Information Network U.S. Census Grids (Summary File 1) (SEDAC, accessed 10 March 2010); https://doi. org/10.7927/H40Z716C

53. Active Mines and Mineral Processing Plants in the United States in 2003 (USGS, 2005); https://mrdata.usgs.gov/mineplant/

54. Diehl, T. H. \& Harris, M. A. Withdrawal and Consumption of Water by Thermoelectric Power Plants in the United States (USGS, 2014); https://doi. org/10.3133/sir20145184

55. Energy Information Administration Form EIA-860 Annual Electric Generator Report (US Department of Energy, 2018); https://www.eia.gov/electricity/data/ eia860/

56. McManamay, R. A. \& Frimpong, E. A. Hydrologic filtering of fish life history strategies across the United States: implications for stream flow alteration. Ecol. Appl. 25, 243-263 (2015)

57. Averyt, K. et al. Water use for electricity in the United States: an analysis of reported and calculated water use information for 2008. Environ. Res. Lett. 8, 015001 (2013).

58. Macknick, J., Newmark, R., Heath, G. \& Hallett, K. C. Operational water consumption and withdrawal factors for electricity generating technologies: a review of existing literature. Environ. Res. Lett. 7, 045802 (2012).

59. Energy Information Administration Form EIA-923 Power Plant Operations Report (US Department of Energy, 2019); https://www.eia.gov/electricity/data/ eia923

60. Digital Distribution Maps of the Freshwater Fishes in the Conterminous United States Version 3.0 (NatureServe, 2010); https://go.nature.com/2OMftE1

61. Bates, D., Maechler, M., Bolker, B. \& Walker, S. Fitting linear mixed-effects models using lme4. J. Stat. Softw. 67, 1-48 (2015).

62. Master, L. L. et al. NatureServe Conservation Status Assessments: Factors for Evaluating Species and Ecosystem Risk (NatureServe, 2012); http:// climatechange.lta.org/natureserve-conservation/

63. Frimpong, E. A. \& Angermeier, P. L. Fish Traits: a database of ecological and life-history traits of freshwater fishes of the United States. Fisheries 34, 487-495 (2009).

64. Mims, M. C. \& Olden, J. D. Life history theory predicts fish assemblage response to hydrologic regimes. Ecology 93, 35-45 (2012).

65. 2012 CFS Public Use Microdata File (US Census Bureau, 2015); https:// go.nature.com/2HeBV19

66. Hwang, H. et al. The Freight Analysis Framework Version 4 (FAF4): Building the FAF4 Regional Database: Data Sources and Estimation Methodologies (Oak Ridge National Laboratory, 2017).

67. Shapefile of CFS Metro Areas for 2012 (US Census Bureau, accessed 24 January 2019); https://www2.census.gov/programs-surveys/cfs/guidance/ cfs-area-shapefile-010215.zip

68. 2012 Commodity Flow Survey Standard Classification of Transported Goods (SCTG), SCTG Commodity Codes CFS-1200 (US Census Bureau, 2011); https://go.nature.com/31M6gRx

69. National Agricultural Statistics Service Quick Stats (US Department of Agriculture, 2016); http://quickstats.nass.usda.gov

70. Mekonnen, M. M. \& Hoekstra, A. Y. A global assessment of the water footprint of farm animal products. Ecosystems 15, 401-415 (2012). 
71. Population Division Estimates of the Resident Population: April 1, 2010 to July 1, 2012 (US Census Bureau, accessed 24 October 2018); https://go.nature. com/38jGd6G

72. Country and Product Trade Data. Exports and Imports Totals 3-digit SITC (US Census Bureau, accessed 24 October 2018); https://www.census.gov/ foreign-trade/statistics/country/sitc/sitc39614digit.xlsx

\section{Acknowledgements}

We dedicate this Article to our esteemed colleague and co-author Arjen Hoekstra, who passed away before this Article could be published. Research support provided by the FEWSION project founded in 2016 by a grant from the INFEWS programme, which is sponsored by the National Science Foundation and the US Department of Agriculture, grant ACI-1639529. The findings and conclusions in this publication are those of the authors and should not be construed to represent any official US Department of Agriculture or US Government determination or policy nor of the other funding entities. K.F.D. was also supported by Columbia University's Data Science Institute and the Earth Institute.

\section{Author contributions}

B.D.R. and B.L.R. provided conceptual design. B.D.R. coordinated individual contribution and wrote the paper. D.B. performed spatial analysis and mapping. P.C. performed hydrologic modelling and interpretation of findings. K.F.D. performed data processing for agricultural water use estimates and virtual water transfer modelling and coordinated input datasets for hydrologic modelling. M.M.M. and A.Y.H. provided agricultural water use estimates. P.D. and T.L. conducted economic assessment of fallowing. R.M. conducted ecological impact analysis. R.R.R. conducted virtual water transfer modelling and provided water use estimates for mining. L.M. provided water use estimates for domestic, commercial, industrial and livestock. T.J.T. provided water use estimates for thermoelectric generation. D.B. contributed spatial analysis and geographic information system mapping. All authors contributed comments and edits to finalize the paper.

\section{Competing interests}

The authors declare no competing interests.

\section{Additional information}

Supplementary information is available for this paper at https://doi.org/10.1038/ \$41893-020-0483-Z.

Correspondence and requests for materials should be addressed to B.D.R

Reprints and permissions information is available at www.nature.com/reprints. Publisher's note Springer Nature remains neutral with regard to jurisdictional claims in published maps and institutional affiliations.

(C) The Author(s), under exclusive licence to Springer Nature Limited 2020 


\section{SUPPLEMENTARY INFORMATION}

\section{Analysis of Fallowing Programs}

We conducted an in-depth analysis of the two largest on-going fallowing programs in the Western US, which are taking place within the Palo Verde Irrigation District (PVID) and the Imperial Irrigation District (IID) in southern California. ${ }^{1,2}$ These districts have been implementing rotational fallowing programs for more than a decade, providing data for evaluating their water conservation potential. Both districts rely upon the Colorado River for irrigation supply. Farmers participating in these two fallowing programs are financially compensated for transferring the water they save from fallowing to public water-supply agencies in the Los Angeles and San Diego metropolitan areas.

The area of farmland fallowed in these two irrigation districts has fluctuated from year to year (Supplementary Figure 5); on average, IID has fallowed $4 \%$ of its cropland and PVID has fallowed $20 \%$. ${ }^{1,2}$ These districts have been able to save an average of 2100 cubic meters of water each year per hectare fallowed, equivalent to 1.3 meters of water depth.

Because all of this saved water is presently transferred out of the local sub-watersheds to urban centers, the water scarcity status (\% depletion) within the farmed watersheds is not improved by these programs; however, the inter-basin transfer of this water has the benefit of supplementing the supply of water - and thereby reducing water scarcity - in the recipient urban watersheds. More than $40 \%$ of the water supply in San Diego County is now derived from the IID rotational fallowing program. ${ }^{2}$ These fallowing programs are providing water for urban use at a very attractive price (USD 0.14-0.16 per cubic meter) as compared to other options for bolstering water supplies, which typically cost 2-10 times as much. ${ }^{3}$

Generally, the least valuable crops are most frequently fallowed in both the PVID and IID; in these two districts, the primary crops fallowed are alfalfa and grass hay. These fallowing programs appear to be financially advantageous for the participating farmers. Within the PVID, the financial compensation paid to farmers does not fully offset their reduced crop revenues (average decrease is USD3,063/hectare), but due to minimal expenses associated with fallowing, the net farming income is attractive. The net income realized on fallowed farms is estimated at 35\%; farm census data indicate that farmers in this area typically earn 10-12\% net income from crop revenues. ${ }^{4}$ Farmers within these districts realize greater profits with fallowing because of the willingness and ability of urban water users (i.e., public water utilities) to pay them an attractive price for their water; this willingness derives from the fact that urban uses of water in services and manufacturing tend to have higher (marginal) economic productivity. ${ }^{5}$ Other important benefits of fallowing include the certainty of receiving fallowing payments, and the opportunity to escape the risk of crop failure.

Within the IID, farmers have also shifted toward more profitable and less water-intensive crops, particularly vegetables and fruits. As a result, district-wide agricultural revenue has increased overall during the fallowing program, even before accounting for fallowing payments and even though some farmland is taken out of production (fallowed). It is possible that these crop shifts were in part financially enabled by fallowing payments on unfarmed lands, but this cannot be verified.

The food security impact of these two fallowing programs is almost certainly negligible. Even if all farmland producing irrigated alfalfa and grass hay in the entire Colorado River basin were fallowed, it 
would amount to less than 5\% of the total US production of these crops. On the other hand, fallowing of these crops across the entire Western US could reduce total US production of these crops by at least one-fourth, which could impact meat and dairy production if alternate sources of alfalfa and grass hay could not be provided, and if producers did not switch to alternate cattle feeds that are available. This suggests that fallowing as a strategy for reducing water scarcity should be carefully targeted and limited to what is necessary to reduce water shortage risks and enhance river ecosystem health.

\section{Methods for analysis of the economics of fallowing}

We divided the treatment area covered by the Palo Verde fallowing program and a comparable, neighboring control area that is not part of the program into $2 \mathrm{~km}$ square grid cells. For each of the 897 grid cells, we determined the fraction of land annually fallowed for $2008-17 .{ }^{6}$ We ran a regression with the fallowed fractions for each year as the dependent variable and the changing program target (i.e., the fraction of total farmland area that is targeted for fallowing) as the primary independent variable; the control area program target was set to zero. We had two specifications. In one, we included plot- (grid cell-) specific fixed effects to control for all factors such as soil quality, geography, slope, etc. that are specific to a plot (grid) but do not vary over time as well as year effects, that capture factors that vary over time such as changing crop prices, temperature, precipitation, etc. and that are common to all (both treated and control) plots. In a second specification we explicitly included next to the plot-specific effects, annual precipitation data and their one-period lag instead of the year effects. The results were very similar. With exogenous program targets (i.e., they are set in San Diego which is outside the fallowing (treatment) area), one can interpret the estimated coefficient of 0.921 as a measure of the effectiveness of the fallowing program. In particular, an increase in Palo Verde's program targets increases fallowing almost one for one - where a coefficient of 1 represents $100 \%$ effectiveness and 0 an ineffective program where either no fallowing occurs or where fallowing happens irrespective of the program. To investigate how the fallowing program affects crop composition, we ran four similar regressions with as dependent variable the fraction of area within each grid cell covered by one of four crop categories ranging from low- to high-value crops. The estimated coefficients from these models provide information on the extent to which the program increases or decreases the cultivated area of each crop category. We applied the same approach to the Imperial Valley program, with one important difference. Because we did not have a credible control area, we could not include year fixed effects, and hence were limited to the second specification. In addition to the plot-specific effects, we included the time-varying variables such as precipitation (and their lags) and in the absence of time fixed effects could not fully account for all possible time-varying factors (including trends in crop changes) that would have occurred irrespective of the fallowing program.

\section{$\underline{\text { References }}$}

1. Metropolitan Water District (MWD) of Southern California. Palo Verde Land Management, Crop Rotation and Water Supply Program (2008). http://www.mwdh20.com/mwdh2o/pages/news/news01.html Accessed August 11, 2011.

2. San Diego County Water Authority (SDCWA). 2010 Urban Water Management Plan. SDCWA, San Diego (2011). 
3. Richter, B.D., Abell, D., Bacha, E., Brauman, K., Calos, S., Cohn, A., Disla, C., Friedlander O’Brien, S., Hodges, D., Kaiser, S., Loughran, M., Mestre, C., Reardon, M. \& Siegfried, E. Tapped out: how can cities secure their water future? Water Policy 15, 335-363 (2013).

4. United States Department of Agriculture, 2012 Census of Agriculture, Volume 1, Chapter 2: County Level.

5. Debaere, P., B.D. Richter, K.F. Davis, M.S. Duvall, J.A. Gephart, C.E. O’Bannon, C. Pelnik, E.M. Powell, and T.W. Smith. 2014. Water markets as a response to scarcity. Water Policy 16, 625649.

6. United States Department of Agriculture, National Agricultural Statistics Service, CropScape and Cropland Data Layer. https://nassgeodata.gmu.edu/CropScape/ (2017). 


\section{Supplementary Table 1. Virtual water trade associated with transfers of US river-irrigated cattle- feed crops and associated beef consumption}

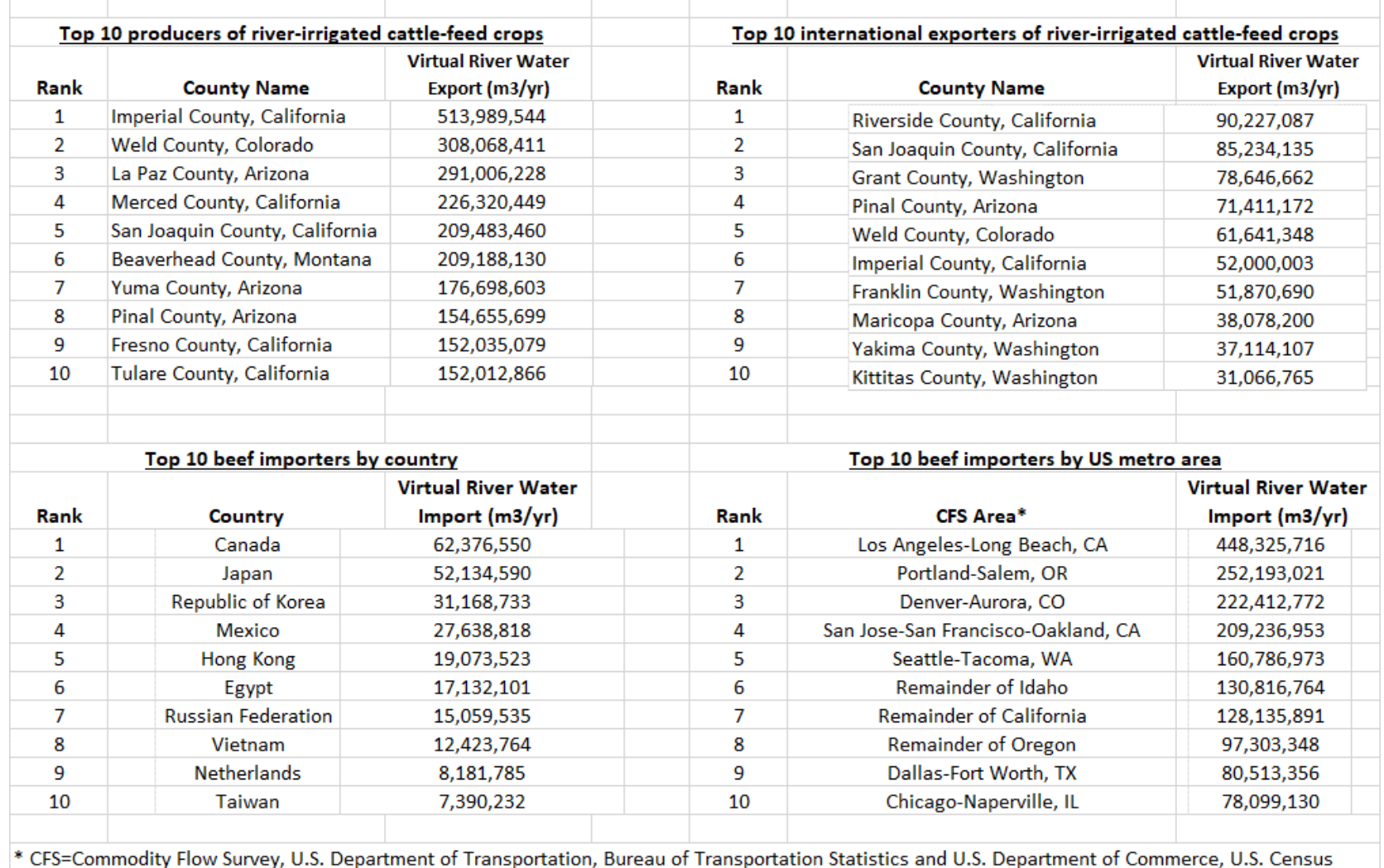

\section{Supplementary Table 2. Causes of summer flow depletion along length of Colorado River, based upon 2001-2015 model simulation.}

\begin{tabular}{|c|c|c|c|c|c|c|c|c|c|c|c|c|}
\hline \multirow[b]{2}{*}{ Location } & \multirow[b]{2}{*}{ HUC8 } & \multirow[b]{2}{*}{$\begin{array}{c}\text { Distance } \\
\text { downstream } \\
(\mathbf{k m})\end{array}$} & \multirow[b]{2}{*}{$\begin{array}{l}\text { Average natural } \\
\text { summer flow } \\
\text { (MCM) }\end{array}$} & \multicolumn{2}{|c|}{$\underline{\text { Inter-Basin Transfers (IBTs) }}$} & \multicolumn{2}{|c|}{ Cattle-Feed Crop Irrigation } & \multicolumn{2}{|c|}{ All Water Uses and IBTs } & \multicolumn{3}{|c|}{ Water Savings from Fallowing } \\
\hline & & & & 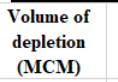 & $\begin{array}{l}\% \text { of total } \\
\text { depletion }\end{array}$ & $\begin{array}{l}\text { Volume of } \\
\text { depletion } \\
\text { (MCM) }\end{array}$ & $\begin{array}{l}\% \text { of total } \\
\text { depletion }\end{array}$ & $\begin{array}{l}\text { Volume of } \\
\text { depletion } \\
\text { (MCM) }\end{array}$ & $\begin{array}{c}\text { Total depletion } \\
(\%)\end{array}$ & $\begin{array}{c}10 \% \\
\text { fallow } \\
(\mathrm{MCM})\end{array}$ & $\begin{array}{c}30 \% \\
\text { fallow } \\
(\mathrm{MCM})\end{array}$ & $\begin{array}{c}50 \% \\
\text { fallow } \\
\text { (MCM) }\end{array}$ \\
\hline Near Glenwood Springs, CO & 14010001 & 0 & 789 & -142 & $75 \%$ & -48 & $25 \%$ & -189 & $-24 \%$ & 5 & 14 & 24 \\
\hline $\begin{array}{l}\text { CO-UT border near } \\
\text { Loma, } \mathrm{CO}\end{array}$ & 14010005 & 224 & 1,819 & -177 & $35 \%$ & -301 & $59 \%$ & -513 & $-28 \%$ & 27 & 80 & 134 \\
\hline Upstream of Moab, UT & 14030001 & 276 & 1,823 & -177 & $35 \%$ & -301 & $59 \%$ & -514 & $-28 \%$ & 27 & 80 & 135 \\
\hline $\begin{array}{l}\text { Confluence with Green River } \\
\text { Canyonlands National Park }\end{array}$ & 14030005 & 433 & 1,990 & -216 & $38 \%$ & -319 & $56 \%$ & -570 & $-29 \%$ & 28 & 85 & 143 \\
\hline Above Lake Powell & 14070001 & 648 & 3,551 & -251 & $26 \%$ & -645 & $67 \%$ & -957 & $-27 \%$ & 53 & 163 & 281 \\
\hline Lake Powell & 14070006 & 753 & 3,865 & -219 & $20 \%$ & -823 & $73 \%$ & $-1,121$ & $-29 \%$ & 65 & 204 & 356 \\
\hline Marble Canyon & 15010001 & 896 & 4,021 & -223 & $20 \%$ & -823 & $74 \%$ & $-1,116$ & $-28 \%$ & 65 & 204 & 356 \\
\hline Grand Canyon & 15010002 & 1,140 & 4,071 & -223 & $20 \%$ & -824 & $74 \%$ & $-1,116$ & $-27 \%$ & 65 & 204 & 357 \\
\hline Lake Mead & 15010005 & 1,321 & 4,119 & -224 & $20 \%$ & -831 & $73 \%$ & $-1,136$ & $-28 \%$ & 66 & 206 & 361 \\
\hline Lake Havasu \& Lake Mohave & 15030101 & 1,567 & 4,121 & -554 & $37 \%$ & -848 & $57 \%$ & $-1,491$ & $-36 \%$ & 67 & 211 & 368 \\
\hline $\begin{array}{l}\text { AZ-CA border, above } \\
\text { confluence with Gila River }\end{array}$ & 15030104 & 1,803 & 4,146 & -554 & $31 \%$ & $-1,096$ & $60 \%$ & $-1,811$ & $-44 \%$ & 88 & 276 & 482 \\
\hline US-Mexico border & 15030107 & 1,858 & 4,968 & $-1,706$ & $34 \%$ & $-1,288$ & $38 \%$ & $-3,347$ & $-67 \%$ & 89 & 279 & 490 \\
\hline Note: Depletion estimates do no & ccount for & oir evaporation & or natural losses & & & & & & & & & \\
\hline $\mathrm{MCM}=$ million cubic meters & & & & & & & & & & & & \\
\hline
\end{tabular}


Supplementary Table 3. Options for attaining demand-management targets in the Colorado River basin

\begin{tabular}{|c|c|c|c|c|}
\hline & $\begin{array}{l}\text { Purpose of demand } \\
\text { management }\end{array}$ & $\begin{array}{c}\text { Demand- } \\
\text { management target } \\
\text { (MCM/year) }\end{array}$ & $\begin{array}{l}\text { Needed } \\
\text { reduction in } \\
\text { cattle-feed } \\
\text { irrigation }\end{array}$ & $\begin{array}{c}\text { Needed } \\
\text { reduction in } \\
\text { inter-basin } \\
\text { transfers }\end{array}$ \\
\hline \multirow{3}{*}{$\begin{array}{l}\text { Upper Basin } \\
\text { (Wyoming, } \\
\text { Colorado, Utah, } \\
\text { New Mexico) }\end{array}$} & Avoid water shortages & 123 & $20 \%$ & $0 \%$ \\
\hline & \multirow{2}{*}{$\begin{array}{l}\text { Avoid water shortages }+ \\
\text { provide ecological protection }\end{array}$} & \multirow{2}{*}{$\begin{array}{c}345 \\
(<20 \% \text { depletion })\end{array}$} & $20 \%$ & $90 \%$ \\
\hline & & & $50 \%$ & $0 \%$ \\
\hline \multirow{4}{*}{$\begin{array}{l}\text { Lower Basin } \\
\text { (Arizona, Nevada, } \\
\text { California) }\end{array}$} & \multirow{3}{*}{ Avoid water shortages } & \multirow{2}{*}{$\begin{array}{c}420 \\
\text { (low range) }\end{array}$} & $44 \%$ & $0 \%$ \\
\hline & & & $20 \%$ & $17 \%$ \\
\hline & & $\begin{array}{c}1480 \\
\text { (high range) }\end{array}$ & $20 \%$ & $81 \%$ \\
\hline & $\begin{array}{l}\text { Avoid water shortages }+ \\
\text { provide ecological protection }\end{array}$ & $\begin{array}{c}2391 \\
(<20 \% \text { depletion })\end{array}$ & $100 \%$ & $76 \%$ \\
\hline
\end{tabular}

$\mathrm{MCM}=$ million cubic meters 




Supplementary Figure 1. Flow depletion estimates under twelve different model simulations: Summer=July-September; All Years=1961-2015 model period; Driest 5 Years=averaged results from driest 10\% of years during 1961-2015; Irrigation=only irrigation water sector modeled; Cattle Feed Crops=only irrigation of cattle-feed crops modeled.
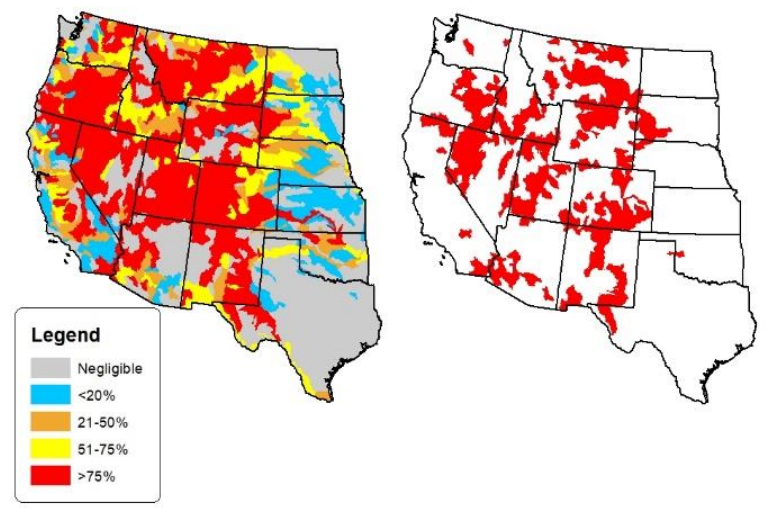

Supplementary Figure 2. River flow depletion due to irrigation of cattle feed crops in the Western US: (a) proportion of total flow depletion attributable to irrigation of cattle-feed crops during summer months (based on July-September averages during 2001-2015 model simulation); (b) sub-watersheds in which flow depletion is $>50 \%$ and cattle-feed irrigation is largest use (based on July-September averages during driest 10\% of years in 1961-2015). 


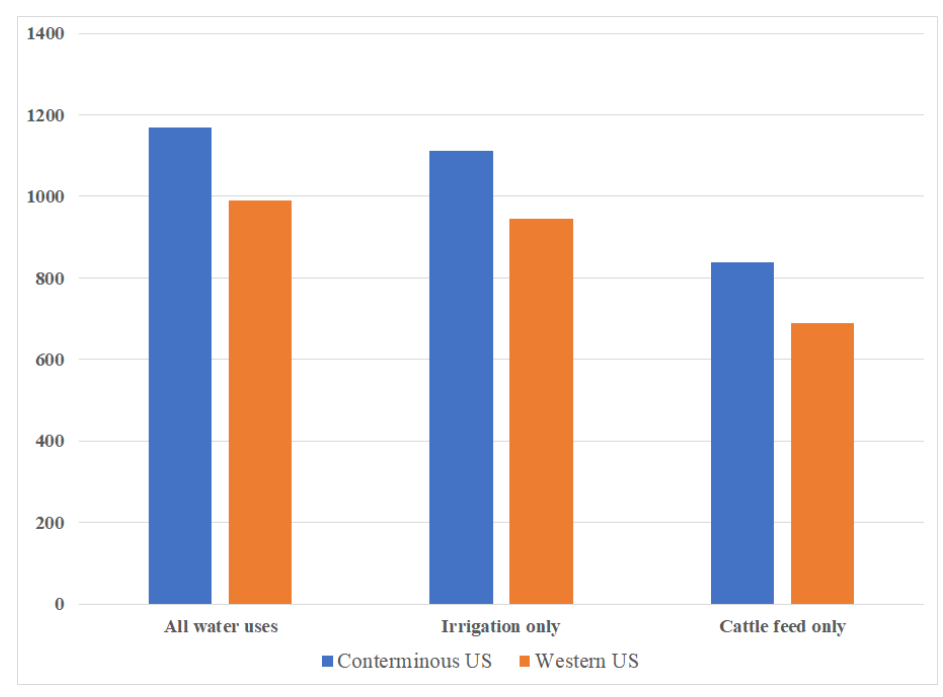

Supplementary Figure 3. Counting local fish extirpations. Model estimates suggest that there are nearly 1,000 instances in which native fish species have been lost or at risk of local extinction from home watersheds in the Western US due to summer flow depletions (based on July-September averages during 2001-2015 modeling simulation), and we estimate nearly all are attributable to water consumed for irrigated agriculture. An estimated 690 (70\%) of these extirpations would have occurred due to irrigation of cattle-feed crops alone, absent any other water uses. Each scenario represents a multiyear average of flows, thus each scenario results in only one solution of estimated local extinctions.

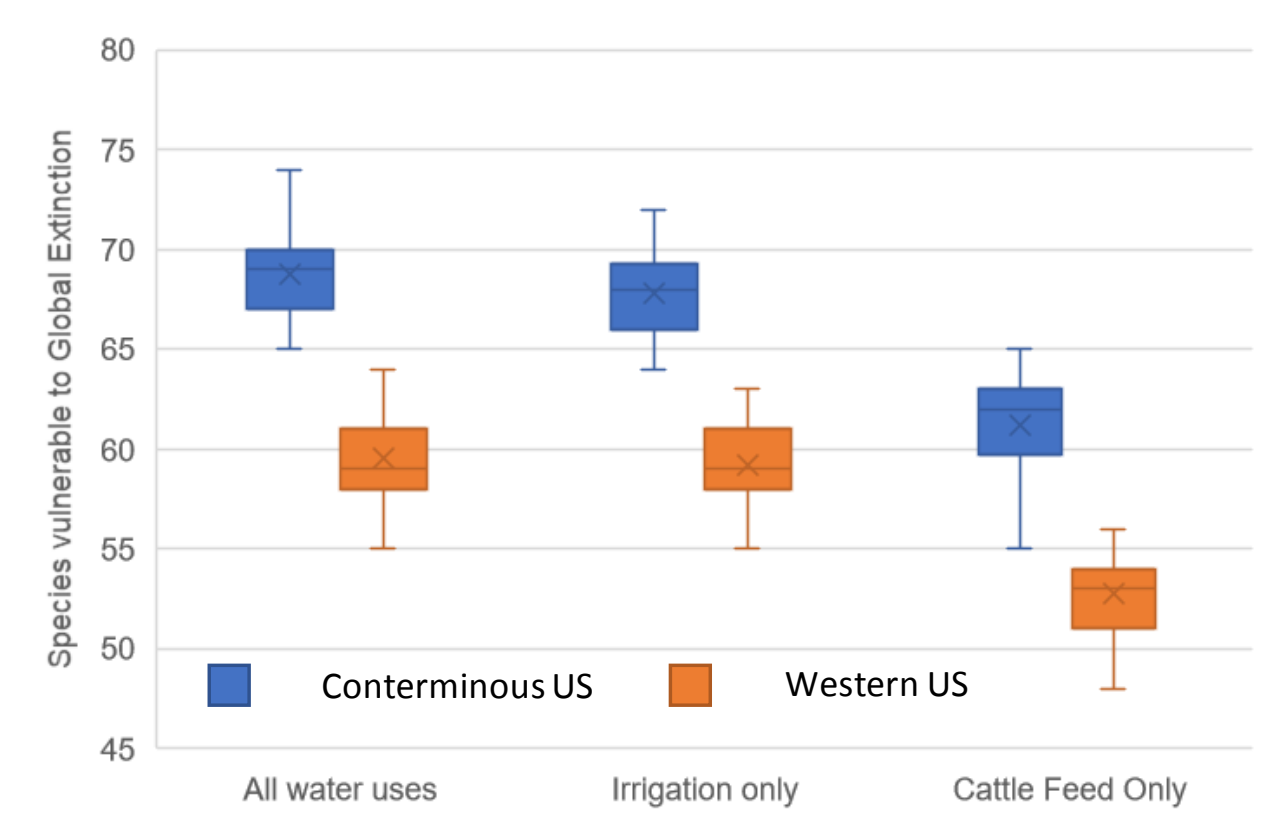

Supplementary Figure 4. Risk of fish imperilment and global extinction. Local extinctions result in range restrictions for species and, when considering current vulnerability status and traits predisposing fish to imperilment, we estimate that almost 60 species are imperiled due to flow depletion and the majority of these (88\%) are due to irrigation of cattle-feed crops. Based on July-September (summer) averages during 2001-2015 model simulation. Box-and-whisker plot for each category represents the median (center line with $X$ ); upper and lower quartiles (box limits); and range limits (whiskers). 
a)

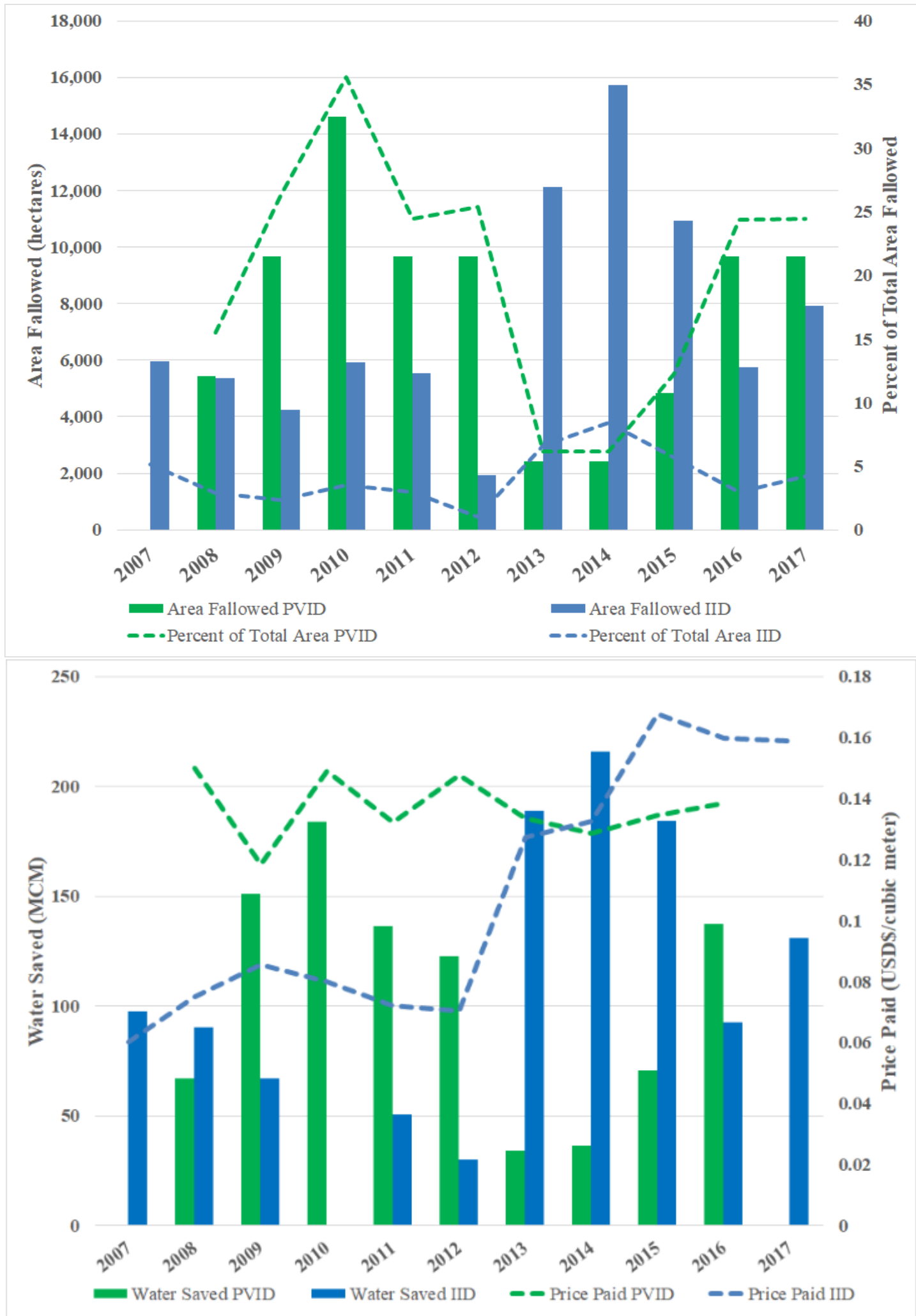

Supplementary Figure 5. Crop fallowing in the Palo Verde Irrigation District (PVID) and Imperial Irrigation District (IID) in southern California. (a) Area and percent of land that has been fallowed; (b) Volume of water saved and transferred, and the price paid by water-supply utilities. MCM=million cubic meters. 
(a)

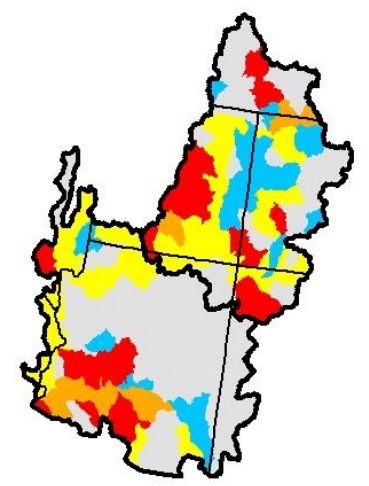

(b)

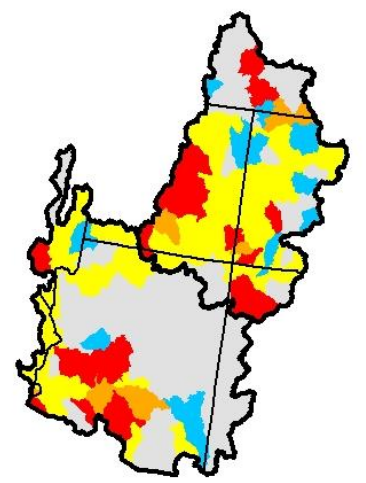

(c)

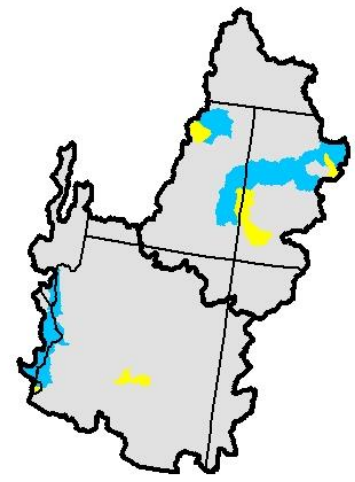

Legend

$<10 \%-11-20 \% \quad 21-50 \%-51-75 \% \square>75 \%$

Supplementary Figure 6. Influence of inter-basin transfers (IBTs) on river depletion estimates. These maps illustrate changes in depletion estimates when IBTs are included in the model simulation for summer (July-September) during 20012015: (a) percent depletion when IBTs not included; (b) percent depletion when IBTs included; (c) percent difference in depletion estimates due to inclusion of IBTs. 